\title{
Guest-Host Interactions in Symmetrical Carboxy Heptamethine Cyanine Dyes-Titanium Dioxide Systems: Synthesis, Theoretical Calculations, Aggregation Properties, and Application in Dye-Sensitized Solar Cells
}

\author{
Rodrigo da Costa Duarte $\mathbb{D}^{\mathbb{D}},{ }^{1}$ Matheus Costa de Oliveira, ${ }^{2}$ Josene Maria Toldo $\left(\mathbb{D},{ }^{3,4}\right.$ \\ Paulo Fernando Bruno Gonçalves $\mathbb{D}^{3},{ }^{3}$ Marcos José Leite Santos $\mathbb{D},^{2}$ \\ and Fabiano Severo Rodembusch (iD ${ }^{1}$ \\ ${ }^{1}$ Grupo de Pesquisa em Fotoquímica Orgânica Aplicada (GPFOA), Instituto de Química, Universidade Federal do Rio Grande do Sul, \\ Av. Bento Gonçalves 9500 CEP 91501-970 Porto Alegre RS, Brazil \\ ${ }^{2}$ Laboratório de Materiais Aplicados e Interfaces (LAMAI), Instituto de Química, Universidade Federal do Rio Grande do Sul, \\ Av. Bento Gonçalves 9500 CEP 91501-970 Porto Alegre RS, Brazil \\ ${ }^{3}$ Grupo de Química Teórica e Computacional, Universidade Federal do Rio Grande do Sul-Instituto de Química, \\ Avenida Bento Gonçalves, 9500, CP 15003, CEP 91501-970 Porto Alegre RS, Brazil \\ ${ }^{4}$ Aix Marseille University, CNRS, ICR, Marseille, France
}

Correspondence should be addressed to Marcos José Leite Santos; mjls@ufrgs.br and Fabiano Severo Rodembusch; rodembusch@iq.ufrgs.br

Received 11 September 2020; Revised 8 December 2020; Accepted 9 January 2021; Published 27 January 2021

Academic Editor: Takuya Fujimura

Copyright ( 2021 Rodrigo da Costa Duarte et al. This is an open access article distributed under the Creative Commons Attribution License, which permits unrestricted use, distribution, and reproduction in any medium, provided the original work is properly cited.

\footnotetext{
In this work, the role of deoxycholic acid (DCA) as a coadsorbent was investigated in the sensitization of mesoporous $\mathrm{TiO}_{2}$ layers (host) with symmetrical carboxy heptamethine cyanine dyes (guest). Different approaches have been tested, aimed at reducing the $\mathrm{H}$-aggregation and minimizing the competition between cyanine molecules and DCA for active sites of the host, thus improving solar cell efficiency. Heptamethine cyanines containing carboxylic anchoring groups were obtained with good yields. The cyanines present UV-Vis absorption in methanol and dimethylformamide solutions ascribed to fully allowed electronic transitions $\left({ }^{1} \pi \pi *\right)$, as well as fluorescence emission in the NIR region, with any evidence of aggregations in both ground and excited states. TD-DFT calculations were also performed in order to study the geometry and charge distribution of these compounds in their ground and excited electronic states. Solid-state photophysics indicates that the cyanines showed excellent adsorption on $\mathrm{TiO}_{2}$, which can be justified by the presence of the $-\mathrm{COOH}$ moieties in the structure. Photophysical measurements have revealed the best concentrations of dye and DCA, which resulted in efficient inhibition of cyanine $\mathrm{H}$-aggregates on the $\mathrm{TiO}_{2}$ surface in addition to allow large dye loading. HOMO and LUMO energy levels of the dyes were identified by cyclic voltammetry, showing oxidation and reduction potentials within acceptable limits for application as a photosensitizer in dye-sensitized solar cells (DSSCs) based on a $\mathrm{TiO}_{2}$ mesoporous photoanode. Assembled DSSCs have shown a large improvement of the electrical parameters and efficiency when a balance between dye aggregation and the competition to the host active sites was reached.
} 


\section{Introduction}

Heptamethine cyanines are organic cationic or neutral compounds, structurally constituted by two heterocyclic nitrogenous portions interconnected by a polymetallic chain [1]. This structural configuration gives these compounds bands of absorption and fluorescence emission that vary from 700 to $1000 \mathrm{~nm}$ and can be modulated according to the number of vinyl groups present in the unsaturated chain [1]. Due to their photophysical properties in the near-infrared, this class of dyes has been explored in many technological applications, such as in hybrid solar cells [2] and nonlinear absorbing materials $[3,4]$, and in bioanalysis, such as enzymatic assays, immunoassays, cancer detection, diagnosis modalities, identification of metallic ions, and $\mathrm{pH}$ studies, and as a drug carrier [5-10]. Yet, special attention has been given to heptamethine cyanines in dye-sensitized solar cell applications [11-17]. These metal-free sensitizers can present some advantages over ruthenium-based complexes, commonly used for sensitization: they are much cheaper and have higher molar extinction coefficients, in addition to present absorption at longer wavelengths [18], and their molecular design - and consequently their obtention-can be easily customized. Nevertheless, the well-known easy formation of aggregates in heptamethine cyanines $[19,20]$ is a major drawback in the particular for applications in DSSC, resulting in decreased solar cell performance $[2,21]$.

To reduce the formation of aggregates on the photoanode, some compounds known as coadsorbers can be applied as additives in the sensitizing dye solution $[2,21]$, such as chenodeoxycholic acid (CDCA) and deoxycholic acid (DCA). Previous works have shown that a lower concentration of the coadsorbent already plays a significant role in solar cell efficiency, while by increasing the concentration, the contribution of $\mathrm{H}$-aggregates is reduced and the solar cell efficiency increases $[20,22]$. In the case of heptamethine cyanines (guest) adsorbed on $\mathrm{TiO}_{2}$ mesoporous film (host), as presented by Ziółek et al., the gain in efficiency can be explained by taking the excited state dynamics of the components into account.

In this paper, we study the effect of aggregation of heptamethine cyanine symmetrical dyes (guest) on $\mathrm{TiO}_{2}$ nanoparticles (host), applying deoxycholic acid (DCA) as a coadsorbent to evaluate the suppression capacity of the dye aggregation. Also, the experimental and theoretical photophysical characterizations of these compounds are presented and discussed, and sensitized solar cells were assembled with an optimized dye : coadsorbent ratio.

\section{Experimental}

2.1. Material and Methods. p-Aminobenzoic acid, 3-methyl2-butanone, sodium acetate, and $\mathrm{SnCl}_{2} \cdot 2 \mathrm{H}_{2} \mathrm{O}$ were purchased from Sigma-Aldrich. $\mathrm{NaNO}_{2}, \mathrm{HCl}, \mathrm{MeOH}$, and $\mathrm{CH}_{3} \mathrm{COOH}$ were acquired from Synth. $\mathrm{POCl}_{3}$ and iodomethane were acquired from Sigma. 4-Methylcyclohexanone, 4-ethylcyclohexanone, and 4-tert-butylcyclohexanone were acquired from Alfa Aesar. Thin layer chromatography was performed using Silica Gel 60 F254. Column chromatog- raphy was performed using Silica Gel $60 \AA$ (70-230 mesh). Infrared spectra were obtained with a Shimadzu-IR PRESTIGE-21 spectrometer in the $\mathrm{NaCl}$ window. The acquisition was made at room temperature with 20 scans and $4.0 \mathrm{~cm}^{-1}$ resolution. ${ }^{1} \mathrm{H}$ and ${ }^{13} \mathrm{C}$ NMR analyses were performed with a Bruker Scientific apparatus operating at $400 \mathrm{MHz}$ for ${ }^{1} \mathrm{H}$ and $100 \mathrm{MHz}$ for ${ }^{13} \mathrm{C}$ or a Varian VNMRS $300 \mathrm{MHz}$ spectrometer operating at $300 \mathrm{MHz}$ for ${ }^{1} \mathrm{H}$ and $75 \mathrm{MHz}$ for ${ }^{13} \mathrm{C}$ using deuterated dimethylsulfoxide $\left(\mathrm{DMSO}-d_{6}\right)$ or chloroform $\left(\mathrm{CDCl}_{3}\right)$. Chemical shifts $(\delta)$ were measured in ppm, and coupling constants $(J)$ in $\mathrm{Hz} .{ }^{1} \mathrm{H}$ NMR spectra were expressed regarding their multiplicity $(s$, singlet; $d$, doublet; $m$, multiplet), coupling constant, and relative number of hydrogens. UV-Vis absorption spectra were obtained with a Shimadzu UV-2450 spectrophotometer in a $10^{-6} \mathrm{M}$ solution at a spectral resolution of $0.1 \mathrm{~nm}$. Solidstate measurements were obtained on a Shimadzu UV-2450 spectrophotometer using an ISR-2200 Integrating Sphere Attachment. The baseline was obtained using $\mathrm{BaSO}_{4}$ (Wako Pure Chemical Industries, Ltd.). In these experiments, the samples were treated as powder. All measurements were carried out at $25^{\circ} \mathrm{C}$. Steady-state fluorescence spectra were obtained using a Shimadzu RF-5301PC spectrofluorometer. The maximum absorption wavelength was set as the excitation radiation for emission measurements. Cyclic voltammetry (CV) was performed on a PalmSens3 potentiostat/galvanostat, using a solution of tetra- $\mathrm{N}$-butylammonium hexafluorophosphate $\left(\mathrm{TBAPF}_{6}\right)$ in $\mathrm{CH}_{2} \mathrm{Cl}_{2}(0.1 \mathrm{M})$ as the supporting electrolyte. A three-electrode cell was used comprised of a glassy carbon electrode as the working electrode, a platinum wire as the counter electrode, and an $\mathrm{Ag} / \mathrm{Ag}^{+}$reference electrode. The cell was deoxygenated by purging with argon before each measurement. Ferrocene/ferricenium $\left(\mathrm{Fc} / \mathrm{Fc}^{+}\right)$redox couple was used as the internal reference. The performance of the DSSCs was evaluated by current versus potential measurements, carried out using a $300 \mathrm{~W}$ xenon arc lamp and an AM1.5 filter. The power of the simulated light was calibrated to $100 \mathrm{~mW} \cdot \mathrm{cm}^{-2}$ and recorded by a picoamperimeter Keithley, model 2400 .

\subsection{Synthesis}

2.2.1. 2,3,3-Trimethyl-3H-indole-5-carboxylic Acid (3). In a round-bottom flask were added 4-hydrazinylbenzoic acid (1) (1.0 g, $6.5 \mathrm{mmol}), 3$-methylbutan-2-one (2) (2.8 g, $32 \mathrm{mmol}$ ), and $40 \mathrm{ml}$ of glacial acetic acid, and the reaction was maintained under reflux for $12 \mathrm{~h}$. After this period, the reaction mixture was concentrated under vacuum, and dichloromethane $(50 \mathrm{ml})$ was added to the flask. Then, this solution was treated with $\mathrm{NaHCO}_{3}$ saturated solution $(1 \times 50 \mathrm{ml})$. The aqueous phase was extracted with dichloromethane $(2 \times 50 \mathrm{ml})$. The combined organic layers were dried using $\mathrm{MgSO}_{4}$ and concentrated under vacuum. The product was obtained in $58 \%$ of yield and used in the next step without purification.

Red solid: yield: $58 \% .{ }^{1} \mathrm{H}$ NMR $\left(\mathrm{CDCl}_{3}, 300 \mathrm{MHz}\right): \delta$ (ppm) $10.54(\mathrm{~s}, 1 \mathrm{H}, J=8.0 \mathrm{~Hz}), 8.16(\mathrm{~d}, 1 \mathrm{H}, J=9.0 \mathrm{~Hz})$, $8.09(\mathrm{~s}, 1 \mathrm{H}), 7.70(\mathrm{~d}, 1 \mathrm{H}, J=9.0 \mathrm{~Hz}), 2.41(\mathrm{~s}, 3 \mathrm{H})$, and 1.38 (s, 6H). ${ }^{13} \mathrm{C} \mathrm{NMR}\left(\mathrm{CDCl}_{3}, 75 \mathrm{MHz}\right): \delta$ (ppm) 192.7, 171.0, $157.0,145.5,130.9,127.5,123.3,119.7,54.0,23.0$, and 15.6. 
2.2.2. 5-Carboxy-1,2,3,3-tetramethyl-3H-indol-1-ium (5). In a round-bottom flask were added $3(0.50 \mathrm{~g}, 2.4 \mathrm{mmol})$, iodomethane (4) ( $1.70 \mathrm{~g}, 12 \mathrm{mmol})$, and acetonitrile $(20 \mathrm{ml})$. The reaction was maintained under $56^{\circ} \mathrm{C}$ for $12 \mathrm{~h}$. After this period, ethyl acetate $(40 \mathrm{ml})$ was added, and the mixture was cooled at room temperature and maintained under agitation for $30 \mathrm{~min}$. Then, the resulting solid was filtered and dried under vacuum. The product was obtained in $65 \%$ of yield and used in the next step without purification.

Pink solid: yield: $65 \%$. M.p.: $251-253^{\circ} \mathrm{C} .{ }^{1} \mathrm{H} \mathrm{NMR}\left(\mathrm{CDCl}_{3}\right.$, $400 \mathrm{MHz}): \delta(\mathrm{ppm}) 8.36(\mathrm{~s}, 1 \mathrm{H}), 8.17(\mathrm{~d}, 1 \mathrm{H}, J=9.0 \mathrm{~Hz}), 8.03$ $(\mathrm{d}, 1 \mathrm{H}, J=9.0 \mathrm{~Hz}), 4.01(\mathrm{~s}, 3 \mathrm{H}), 2.84(\mathrm{~s}, 3 \mathrm{H})$, and $1.57(\mathrm{~s}, 6 \mathrm{H})$. ${ }^{13} \mathrm{C} \mathrm{NMR}\left(\mathrm{CDCl}_{3}, 100 \mathrm{MHz}\right): \delta$ (ppm) 199.4, 166.9, 145.7, $142.3,131.9,130.7,124.6,115.8,54.7,35.6,21.9$, and 15.2 .

2.2.3. Pentamethinic Salts $(11 a-c)$. In a round-bottom flask cooled to $0^{\circ} \mathrm{C}, 2.4 \mathrm{ml}$ of DMF $(2.26 \mathrm{~g}, 31 \mathrm{mmol})$ and $2 \mathrm{ml}$ of $\mathrm{POCl}_{3}(3.37 \mathrm{~g}, 22 \mathrm{mmol})$ were added dropwise, and this mixture was stirred for 30 minutes. After $1.13 \mathrm{ml}$ of cyclohexanone $6(1.07 \mathrm{~g}, 9.6 \mathrm{mmol})$ was added, the reaction mixture was kept under stirring and reflux for $2 \mathrm{~h}$. After this period, the reaction temperature was reduced to room temperature and a mixture of aniline (10) and ethanol $[1: 1(v / v)$, $3.3 \mathrm{ml}$ ] was added and kept under stirring for $1 \mathrm{~h}$. After this period, the reaction crude was poured into a mixture of ice and concentrated $\mathrm{HCl}(10: 1,20 \mathrm{ml})$ for $12 \mathrm{~h}$. After this period, the resulting solid was filtered and washed as $\mathrm{H}_{2} \mathrm{O}$, recrystallized from toluene, filtered with filter paper, and dried under vacuum. A similar procedure was performed for obtaining the compounds $11 \mathrm{~b}$ and $11 \mathrm{c}$ using cyclohexanones 7 and 8 , respectively.

$N-((E)-((E)-2-C h l o r o-5-m e t h y l-3-((p h e n y l a m i n o) m e t h y-$ lene)cyclohex-1-en-1-yl)methylene)benzenaminium chloride (11a): violet solid. Yield: $70 \%$ (2.50 g). M.p.: $221^{\circ}$ C. FTIR $\left(\mathrm{cm}^{-1}\right): 3042,2946,2868,1607,1565,1465$, and $1297 .{ }^{1} \mathrm{H}$ NMR (DMSO- $\left.d_{6}, 400 \mathrm{MHz}\right): \delta(\mathrm{ppm}) 11.22(\mathrm{~s}, 2 \mathrm{H}), 8.53(\mathrm{~s}$, 2H), 7.58 (m, 4H), $7.44(\mathrm{~m}, 4 \mathrm{H}), 7.25(\mathrm{~m}, 2 \mathrm{H}), 3.02(\mathrm{~m}, 2 \mathrm{H})$, $2.22(\mathrm{~m}, 2 \mathrm{H}), 1.92(\mathrm{~m}, 1 \mathrm{H})$, and $1.14(\mathrm{~d}, 3 \mathrm{H}, J=4.0 \mathrm{~Hz})$.

$N-((E)-((E)-2-C h l o r o-5-e t h y l-3-(($ phenylamino $)$ methylene $)-$ cyclohex-1-en-1-yl)methylene)benzenaminium chloride (11b): violet solid. Yield: $58 \%(2.15 \mathrm{~g})$. M.p.: $219-222^{\circ} \mathrm{C}$. FTIR $\left(\mathrm{cm}^{-1}\right)$ : 3090, 2958, 2855, 1607, 1565, 1453, and 1261. ${ }^{1} \mathrm{H}$ NMR (DMSO- $\left.d_{6}, 300 \mathrm{MHz}\right): \delta(\mathrm{ppm}) 11.34(\mathrm{~s}, 2 \mathrm{H}), 8.51(\mathrm{~s}, 2 \mathrm{H})$, $7.60(\mathrm{~m}, 4 \mathrm{H}), 7.44(\mathrm{~m}, 4 \mathrm{H}), 7.25(\mathrm{~m}, 2 \mathrm{H}), 3.09(\mathrm{~m}, 2 \mathrm{H}), 2.18$ $(\mathrm{m}, 2 \mathrm{H}), 1.65(\mathrm{~m}, 1 \mathrm{H}), 1.47(\mathrm{q}, 2 \mathrm{H}, J=7.2 \mathrm{~Hz})$, and $1.05(\mathrm{t}$, $3 \mathrm{H}, J=7.2 \mathrm{~Hz})$.

$N-((E)-((E)-5-($ tert-Butyl)-2-chloro-3-((phenylamino)methylene)cyclohex-1-en-1-yl)methylene)benzenaminium chloride (11c): violet solid. Yield: 75\% (2.99 g). M.p.: 217-219 C; FTIR $\left(\mathrm{cm}^{-1}\right): 3060,2952,2874,1607,1571,1469$, and $1267 .{ }^{1} \mathrm{H}$ NMR (DMSO- $\left.d_{6}, 400 \mathrm{MHz}\right): \delta(\mathrm{ppm}) 11.40(\mathrm{~s}, 2 \mathrm{H}), 8.52(\mathrm{~s}$, $2 \mathrm{H}), 7.58(\mathrm{~m}, 4 \mathrm{H}), 7.46(\mathrm{~m}, 4 \mathrm{H}), 7.27(\mathrm{~m}, 2 \mathrm{H}), 3.06(\mathrm{~m}, 2 \mathrm{H})$, $2.14(\mathrm{~m}, 2 \mathrm{H}), 1.47(\mathrm{~m}, 1 \mathrm{H})$, and $1.05(\mathrm{~m}, 9 \mathrm{H})$.

2.2.4. Carboxy Heptamethine Cyanines (12-14). In a roundbottomed monotubulated amber flask, $20 \mathrm{ml}$ of isopropanol was added and subsequently closed with a septum. Then, $\mathrm{N}_{2}$ was bubbled through the isopropanol for $15 \mathrm{~min}$. After bubbling with nitrogen, compound $11 \mathrm{a}(0.18 \mathrm{~g}, 0.5 \mathrm{mmol})$,
$\mathrm{CH}_{3} \mathrm{COONa} \quad(0.12 \mathrm{~g} \quad 1.5 \mathrm{mmol})$, and indole $5 \quad(0.51 \mathrm{~g}$ $1.5 \mathrm{mmol})$ were added. The reaction mixture was kept at reflux, under $\mathrm{N}_{2}$ atmosphere for $18 \mathrm{~h}$. At the end of the reaction, the solvent was evaporated under reduced pressure. The obtained solid was purified by washing with $150 \mathrm{ml}$ of dichloromethane, carried out in an ultrasound bath for $30 \mathrm{~min}$. After 12 hours, this washing process was repeated 4 times. The obtained solid was filtered through filter paper and washed with $40 \mathrm{ml}$ distilled water followed by $15 \mathrm{ml}$ ethyl ether. Then, the obtained solid was filtered through filter paper and dried under vacuum. A similar procedure was performed for obtaining the compounds 13 and 14 using the intermediates $11 \mathrm{~b}$ and $11 \mathrm{c}$, respectively.

5-Carboxy-2-((E)-2-((E)-3-(2-((E)-5-carboxy-1,3,3-trimethylindolin-2-ylidene)ethylidene)-2-chloro-5-methylcyclohex-1-en-1-yl)vinyl)-1,3,3-trimethyl-3H-indol-1-ium iodide (12): green solid. Yield: 52\% (0.18 g). M.p.: 257-259 ${ }^{\circ}$ C. FTIR $\left(\mathrm{cm}^{-1}\right): 3423,3052,2966,2878,1704$, and 1548. ${ }^{1} \mathrm{H}$ NMR $\left(\mathrm{DMSO}_{\mathrm{d}}, 400 \mathrm{MHz}\right): \delta(\mathrm{ppm}) 8.27(\mathrm{~d}, 2 \mathrm{H}, J=16.0 \mathrm{~Hz})$, $8.14(\mathrm{~s}, 1 \mathrm{H}), 8.02(\mathrm{~d}, 2 \mathrm{H}, J=12.0 \mathrm{~Hz}), 7.52(\mathrm{~d}, 2 \mathrm{H}, J=12.0$ $\mathrm{Hz}), 6.37(\mathrm{~d}, 2 \mathrm{H}, J=12.0 \mathrm{~Hz}), 3.71(\mathrm{~s}, 6 \mathrm{H}), 2.96(\mathrm{~m}, 2 \mathrm{H})$, $2.20(\mathrm{~m}, 2 \mathrm{H}), 1.93(\mathrm{~m}, 1 \mathrm{H})$, and $1.69(\mathrm{~s}, 12 \mathrm{H}), 1.16(\mathrm{~d}$, $3 \mathrm{H}, J=8.0 \mathrm{~Hz}) .{ }^{13} \mathrm{C}$ NMR $\left(\mathrm{DMSO}_{6}, 100 \mathrm{MHz}\right): \delta(\mathrm{ppm})$ $173.9,167.3,148.9,146.9,143.8,141.6,131.0,127.7,127.6$, 123.7, 111.7, 103.5, 49.1, 34.0, 32.4, 27.7, 27.6, and 21.3.

5-Carboxy-2-((E)-2-((E)-3-(2-((E)-5-carboxy-1,3,3-trimethylindolin-2-ylidene)ethylidene)-2-chloro-5-ethylcyclohex-1en-1-yl)vinyl)-1,3,3-trimethyl-3H-indol-1-ium iodide (13): green solid. Yield: $57 \%$ (0.20 g). M.p.: 251-254 ${ }^{\circ} \mathrm{C}$. FTIR $\left(\mathrm{cm}^{-1}\right): 3423$, 3052, 2966, 2869, 1704, and 1557. ${ }^{1} \mathrm{H}$ NMR (DMSO-d 6 , $400 \mathrm{MHz}): \delta(\mathrm{ppm}) 8.27(\mathrm{~d}, 2 \mathrm{H}, J=12.0 \mathrm{~Hz}), 8.13(\mathrm{~s}, 1 \mathrm{H})$, $8.01(\mathrm{~d}, 2 \mathrm{H}, J=8.0 \mathrm{~Hz}), 7.51(\mathrm{~d}, 2 \mathrm{H}, J=8.0 \mathrm{~Hz}), 6.39(\mathrm{~d}, 2 \mathrm{H}$, $J=12.0 \mathrm{~Hz}), 3.71(\mathrm{~s}, 6 \mathrm{H}), 2.97(\mathrm{~m}, 2 \mathrm{H}), 2.21(\mathrm{~m}, 2 \mathrm{H}), 1.68(\mathrm{~s}$, 12H), $1.49(\mathrm{~m}, 2 \mathrm{H})$, and $1.04(\mathrm{t}, 3 \mathrm{H}, J=8.0 \mathrm{~Hz}) .{ }^{13} \mathrm{C} \mathrm{NMR}$ $\left(\mathrm{DMSO}_{6}, 100 \mathrm{MHz}\right): \delta$ (ppm) 173.9, 167.3, 149.0, 146.9, 143.9, 141.6, 131.0, 127.7, 127.6, 123.7, 111.7, 103.4, 49.1, 33.8, $32.3,31.9,28.2,27.6(2 \mathrm{C})$, and 11.9.

2-((E)-2-((E)-5-(tert-Butyl)-3-(2-((E)-5-carboxy-1,3,3-trimethylindolin-2-ylidene)ethylidene)-2-chlorocyclohex-1-en-1yl)vinyl)-5-carboxy-1,3,3-trimethyl-3H-indol-1-ium iodide (14): green solid. Yield: 53\% (0.20 g). M.p.: 260-265 C. FTIR $\left(\mathrm{cm}^{-1}\right): 3432,3034,2966,2878,1695$, and 1557. ${ }^{1} \mathrm{H}$ NMR $\left(\mathrm{DMSO}_{-}, 400 \mathrm{MHz}\right): \delta(\mathrm{ppm}) 8.28(\mathrm{~d}, 2 \mathrm{H}, J=12.0 \mathrm{~Hz})$, $8.12(\mathrm{~s}, 1 \mathrm{H}), 8.01(\mathrm{~d}, 2 \mathrm{H}, J=12.0 \mathrm{~Hz}), 7.50(\mathrm{~d}, 2 \mathrm{H}, J=6.0$ $\mathrm{Hz}), 6.39(\mathrm{~d}, 2 \mathrm{H}, J=12.0 \mathrm{~Hz}), 3.72(\mathrm{~s}, 6 \mathrm{H}), 2.96(\mathrm{~m}, 2 \mathrm{H})$, $2.19(\mathrm{~m}, 2 \mathrm{H}), 1.69(\mathrm{~s}, 12 \mathrm{H}), 1.49(\mathrm{~m}, 1 \mathrm{H})$, and $1.05(\mathrm{~s}, 9 \mathrm{H})$. ${ }^{13} \mathrm{C}$ NMR (DMSO-d $\left.6,100 \mathrm{MHz}\right): \delta(\mathrm{ppm})$ 173.9, 167.3, $149.0,146.9,143.9,141.6,131.0,128.4,127.5,123.7,111.7$, $103.2,49.2,32.7,32.3,29.9,27.7$, and 27.6.

2.3. Theoretical Calculations. Theoretical calculations were done using Density Functional Theory (DFT) and TimeDependent Density Functional Theory (TD-DFT) with Gaussian 16 RevA.03 [23] program. The structures of the ground $\left(\mathrm{S}_{0}\right)$ and first excited singlet $\left(\mathrm{S}_{1}\right)$ states were optimized using the M06-2X functional [24] and 6-31G(d,p) basis set [25]. This functional was selected after a benchmarking against the experimental values of absorption and emission maxima wavelengths. Yet, previous works have 
TABLE 1: Experimental conditions for the study of coadsorption of deoxycholic acid (DCA) and cyanine 13 as a model in methanol solutions on $\mathrm{TiO}_{2}$ mesoporous layer.

\begin{tabular}{|c|c|c|}
\hline Methodology & Type & Conditions \\
\hline$\# 1$ & \multirow{4}{*}{ One-step adsorption } & $\begin{array}{l}\text { Dye concentration: } 5.0 \mathrm{mM} \text {; DCA concentrations: } 2,6,20 \text {, and } 40 \mathrm{mM} ; \mathrm{TiO}_{2} \text { temperature: } \\
\qquad 80^{\circ} \mathrm{C} \text {; adsorption time: } 24 \mathrm{~h}\end{array}$ \\
\hline$\# 2$ & & $\begin{array}{l}\text { Dye concentration: } 5.0 \mathrm{mM} \text {; DCA concentrations: } 2,6,20 \text {, and } 40 \mathrm{mM} ; \mathrm{TiO}_{2} \text { temperature: } \\
\qquad 22^{\circ} \mathrm{C} \text {; adsorption time: } 24 \mathrm{~h}\end{array}$ \\
\hline$\# 3$ & & $\begin{array}{l}\text { Dye concentration: } 5.0 \mathrm{mM} \text {; DCA concentrations: } 2,6,20 \text {, and } 40 \mathrm{mM} ; \mathrm{TiO}_{2} \text { temperature: } \\
\qquad 22^{\circ} \mathrm{C} \text {; adsorption time: } 1 \mathrm{~h}\end{array}$ \\
\hline$\# 4$ & & $\begin{array}{l}\text { Dye concentration: } 0.1 \mathrm{mM} \text {. DCA concentrations: } 2,6 \text {, and } 20 \mathrm{mM} ; \mathrm{TiO}_{2} \text { temperature: } \\
\qquad 22^{\circ} \mathrm{C} \text {; adsorption time: } 1 \mathrm{~h}\end{array}$ \\
\hline$\# 5$ & Two-step adsorption & $\begin{array}{l}\text { First step: DCA concentrations-2, } 6 \text {, and } 20 \mathrm{mM} \text {; Second step: dye concentration-0.1 mM; } \\
\qquad \mathrm{TiO}_{2} \text { temperature: } 22^{\circ} \mathrm{C} \text {; adsorption time: } 1 \mathrm{~h}\end{array}$ \\
\hline
\end{tabular}

pointed out the efficiency of hybrid functionals with $\sim 50 \%$ of the Hartree-Fock exchange to simulate the electronic spectra of cyanine dyes, with average errors of $0.29 \mathrm{eV}$ for the M06$2 \mathrm{X}$ functional [26-28]. The minimum energies structures were verified by vibrational analysis. Vertical absorption and emission energies were computed at the M06-2X/6$311+G(d, p)$ level of theory. The solvent effects were included by applying the integral equation formalism of the polarizable continuum model (IEF-PCM) [29-31] using methanol and $N, N$,-dimethylformamide (DMF) as solvents. To analyze the character of the excitations, natural transition orbitals (NTOs) [32] were obtained at the same level of theory using the Gaussian 16 program. For insights on the power conversion efficiency of DSSC devices, we also calculated the HOMO-LUMO band gaps, ESP (electrostatic surface potential) analysis using charges derived from potential (ChelpG), and light harvesting efficiency (LHE) from DFT/TD-DFT calculations.

2.4. DSSC Preparation. The $\mathrm{TiO}_{2}$ paste was screenprinted on the transparent conductive substrate (fluorine-doped tin oxide, FTO) previously soaked in a $40 \mathrm{mM} \mathrm{TiCl}_{4}$ aqueous solution at $60^{\circ} \mathrm{C}$ for 30 minutes. The substrate was heated on a hot plate at $125^{\circ} \mathrm{C}$ for $20 \mathrm{~min}$ and at $450^{\circ} \mathrm{C}$ for $30 \mathrm{~min}$ in a tubular oven. The mesoporous $\mathrm{TiO}_{2}$ electrode was immersed in $0.1 \mathrm{mM}$ of 13 and kept at room temperature $24 \mathrm{~h}$ (see Section 2.6). The counterelectrodes were prepared by coating the FTO surface with $30 \mu \mathrm{l}$ of $1 \mathrm{mM}$ hexachloroplatinic acid and heated at $500^{\circ} \mathrm{C}$. The mediator, responsible for the regeneration of the dye, was placed in between the dye-sensitized photoanode and the counterelectrode. The device was sealed using a polymeric film of low melting temperature (Meltonix). The electrolyte was a $0.6 \mathrm{M}$ BMII, $0.03 \mathrm{M} \mathrm{I}_{2}, 0.10 \mathrm{M}$ guanidinium thiocyanate, and 4-tertbutylpyridine $(0.5 \mathrm{M})$ in a mixture of acetonitrile and valeronitrile. Additional information for the anode and cathode preparation can be found as supplementary material.

2.5. Coadsorption Study. Five different methodologies of adsorption on the mesoporous $\mathrm{TiO}_{2}$ films were proposed and evaluated (1-5) using compound 13 as a model (Table 1). In this study, the aggregation effect was evaluated taking the intensity of the H-aggregate absorption band located at around $700 \mathrm{~nm}$ into account (Figure 1).
2.6. Electrical Characterization of the Assembled Devices. Electrical current versus electrical potential curves $(I-V)$ were acquired within the range of $-0.2 \mathrm{~V}$ to $+1.1 \mathrm{~V}$ with seventeen different voltage levels (mean interval of $75 \mathrm{mV}$ ) to characterize the DSSCs. The experiments were carried out using a xenon lamp of $300 \mathrm{~W}$, with an incident light intensity of $100 \mathrm{~mW} \cdot \mathrm{cm}^{-2}$, fed by a source model 66485 using a filter AM1.5 and a picoammeter Keithley model 2410-c. Light intensity was measured by using a photodiode model 71648-71608.

\section{Results and Discussion}

3.1. Synthesis. The carboxy heptamethine cyanine dyes 12-14 were prepared as presented in Scheme 1. The heterocyclic compound 3 was prepared according to the literature [33]. Initially, 4-hydrazinobenzoic acid (1) reacted with 3-methylbutan-2-one (2) under reflux to obtain the intermediate compound 2,3,3-trimethyl-3H-indole-5-carboxylic acid (3) by Fischer cyclization [34]. Then, 3 was alkylated with iodomethane (4) in a nitrogen atmosphere to obtain the quaternized indole 5 .

Pentamethinic salts $11 \mathrm{a}-\mathrm{c}$ were synthesized from an adapted methodology already described in the literature [35]. The methodology consists of two steps, employing a formylating system containing the respective hexanones 6-8 and $\mathrm{POCl}_{3} / \mathrm{DMF} / \mathrm{PhNH}_{3}{ }^{+} \mathrm{Cl}^{-}$. In the first step, there is the formation of the Vilsmeier-Haack reagent through the slow addition of $\mathrm{POCl}_{3}$ in DMF under an ice bath, which generated a reddish solution evidencing the formation of chlorine ion. Then, the respective cyclohexanone was added under an ice bath. In the second step, an alcoholic solution of aniline was added to the reaction mixture at room temperature and left under stirring in an acidic medium. The compounds $11 \mathrm{a}-\mathrm{c}$ were obtained with crude yields between 58 and $75 \%$.

The synthetic method for obtaining the desired compounds 12-14 occurs similar to the Knoevenagel condensation, but in this case, the condensation reactions take place between the bis iminic pentamethine salts $11 \mathrm{a}-\mathrm{c}$ with compound 5 using sodium acetate as the base and isopropyl alcohol (HPLC grade) as the solvent under reflux (Scheme 1). To minimize the photooxidation processes that can be prejudicial to the stability of these structures [36], the synthesis was performed in the dark with the use of amber glassware 


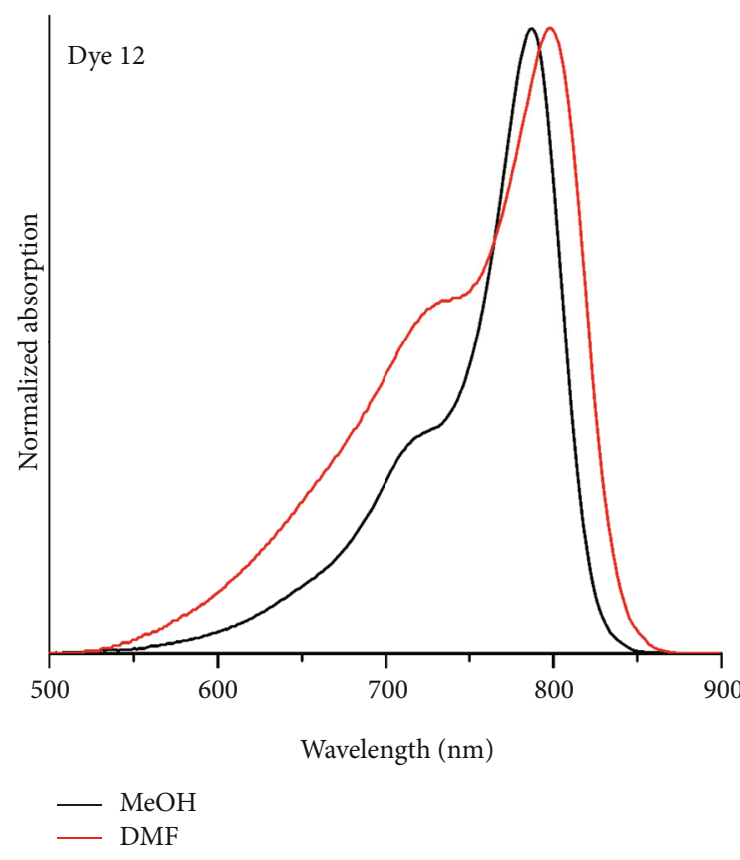

(a)

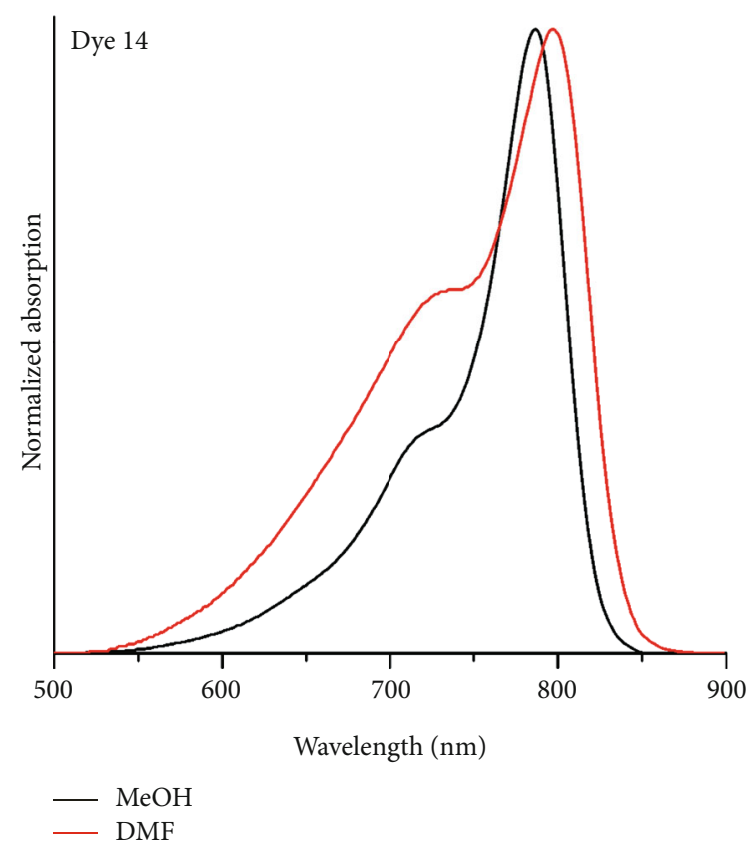

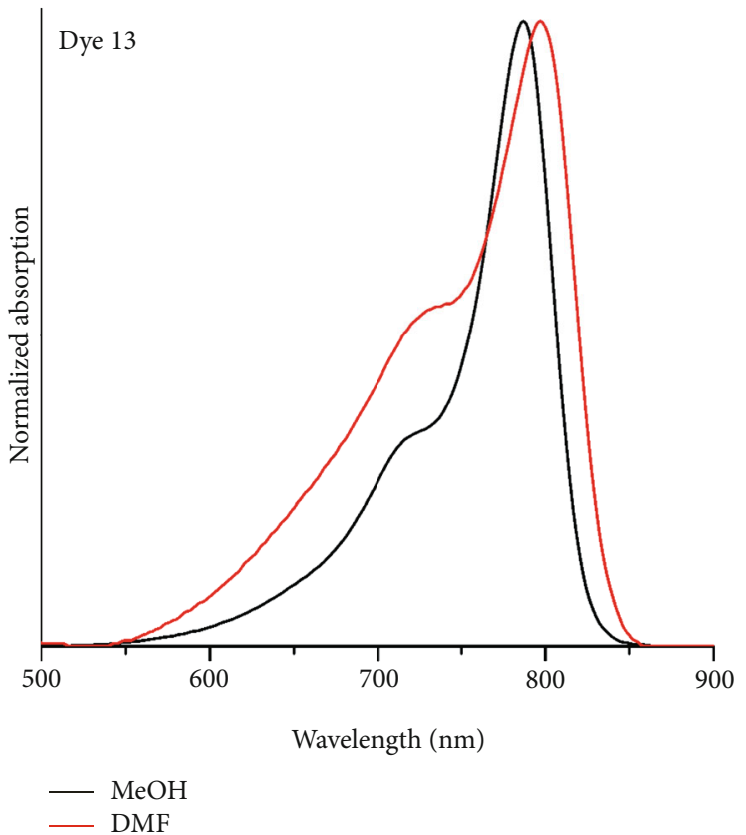

(b)

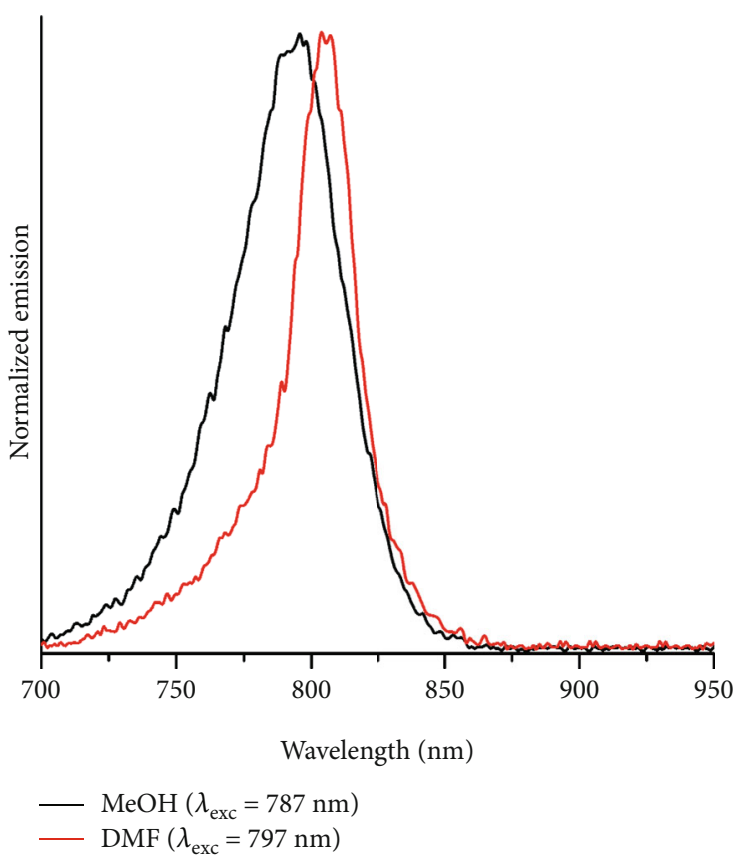

(d)

FIgURE 1: Continued. 


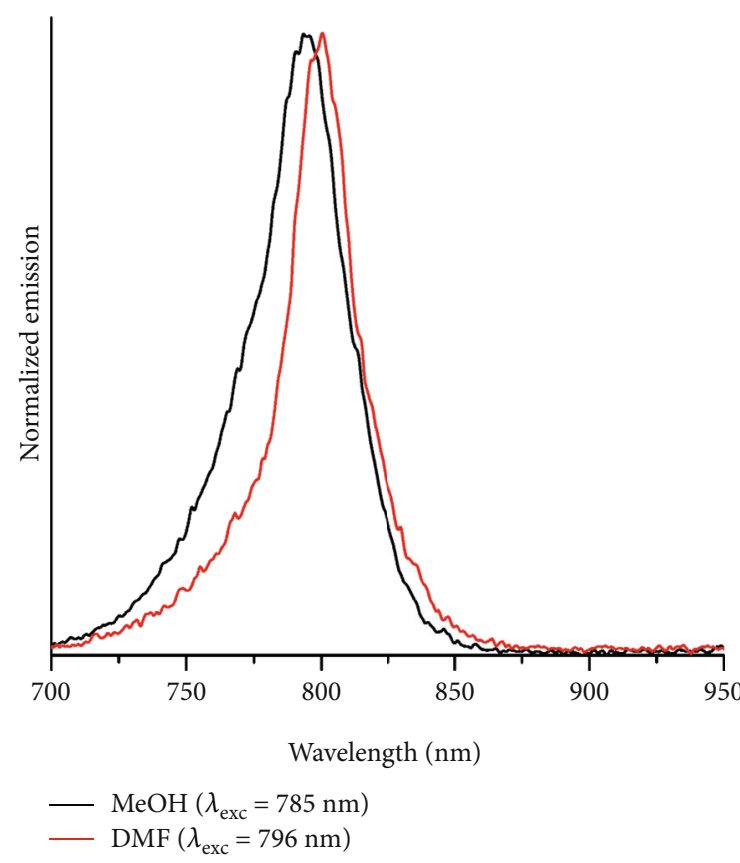

(e)

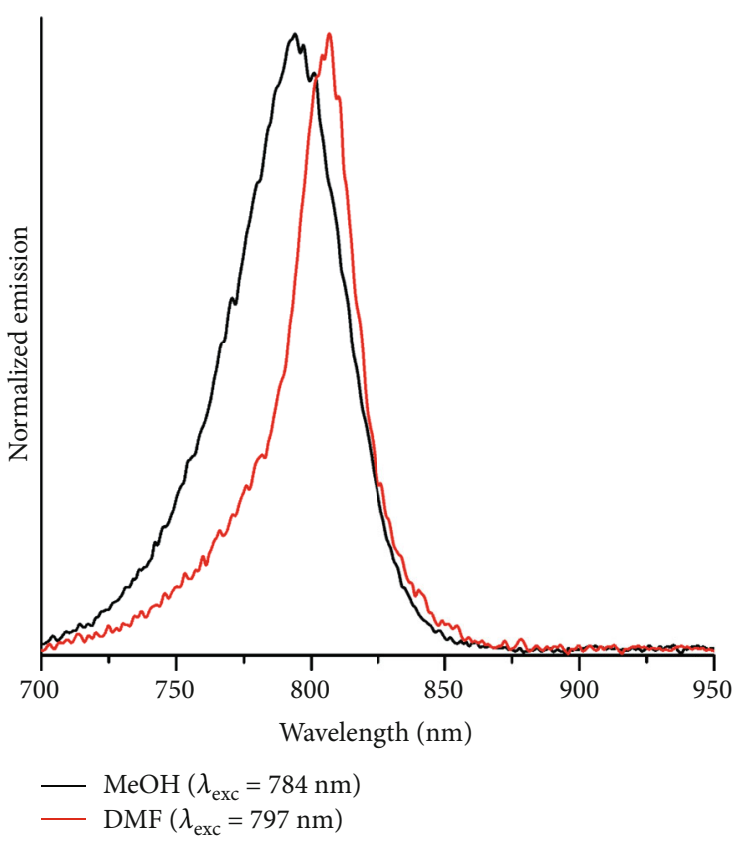

(f)

FIGURE 1: Normalized solid-state absorption spectra (DRUV) of cyanine 13 in $\mathrm{TiO}_{2}$ film obtained from different adsorption methodologies (a) \#1, (b) \#2, (c) \#3, (d) \#4, and (e) \#5. The image of the $\mathrm{TiO}_{2}$ film sensitized under the proposed conditions of methodology \#4, with $20 \mathrm{mM}$ DCA (left) and $40 \mathrm{mM}$ DCA (right) is also presented for comparison.

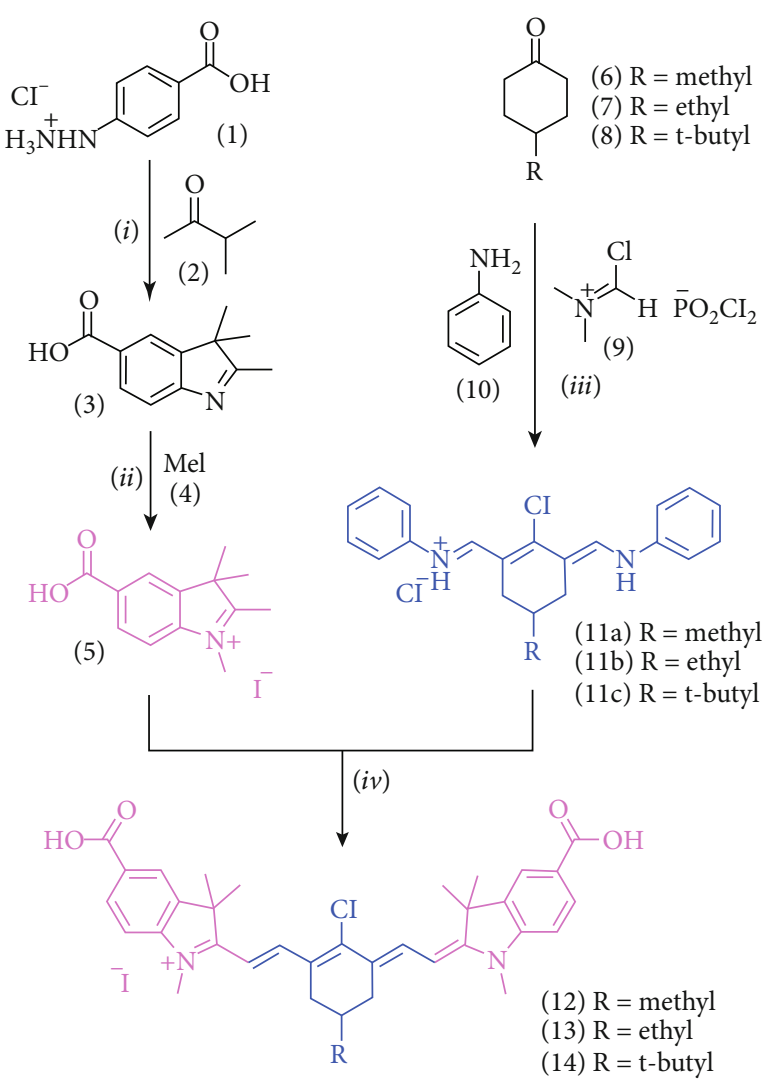

Scheme 1: Synthesis of heptamethine cyanines 12-14, where (i) $\mathrm{CH}_{3} \mathrm{COOH} /$ reflux; (ii) $\mathrm{CH}_{3} \mathrm{CN} / 56^{\circ} \mathrm{C}$, (iii) 1: $\mathrm{DMF}, 0-110^{\circ} \mathrm{C}, 2$ : aniline/EtOH, $0^{\circ} \mathrm{C}$; (iv) dark, $\mathrm{N}_{2}, i-\mathrm{PrOH}, \mathrm{CH}_{3} \mathrm{COONa} /$ reflux. and under $\mathrm{N}_{2}$ atmosphere. The final compounds were purified by precipitation and obtained in moderate yields ( 50\%). The spectroscopic characterization was performed for all intermediates and final compounds and is presented as supplementary material.

3.2. Photophysical Characterization. The UV-Vis absorption spectra of the heptamethine dyes 12-14 in the solution are shown in Figure 2. The relevant data from the photophysical characterization are summarized in Table 2. The compounds 12-14 present absorption maxima located in the NIR region, between 784 and $797 \mathrm{~nm}$. The molar absorptivity coefficient values $\left(\varepsilon \sim 105 \mathrm{~cm}^{-1} \cdot \mathrm{M}^{-1}\right)$ indicate allowed electronic transitions, which could be related to ${ }^{1} \pi \pi *$ transitions. For conjugated systems, these transitions are associated with a small optical band gap $\left(E_{g}^{\mathrm{opt}} \sim 1.4 \mathrm{eV}\right)$ between the HOMO and LUMO orbitals compared to chromophores that absorb in the Vis-NIR region.

The shape of the absorption bands in Figure 2 indicates an influence of vibrational and intermolecular interactions. The decrease of vibrational interactions leads to a narrowing of the absorption band, while the increase of intermolecular interactions leads to an enlargement of the absorption band. A less intense absorption band was observed around $720 \mathrm{~nm}$. Although, according to the literature, this peak could be related to the formation of $\mathrm{H}$-type aggregates $[16,20,22$, 37], its intensity suggests that, in this case, this band seems to be related to $S_{0} \longrightarrow S_{2}$ electronic transitions. In fact, the formation of these aggregates in solution could be related to the lower solubility of these compounds in more polar solvents, leading to the formation of self-organized structures allowed 


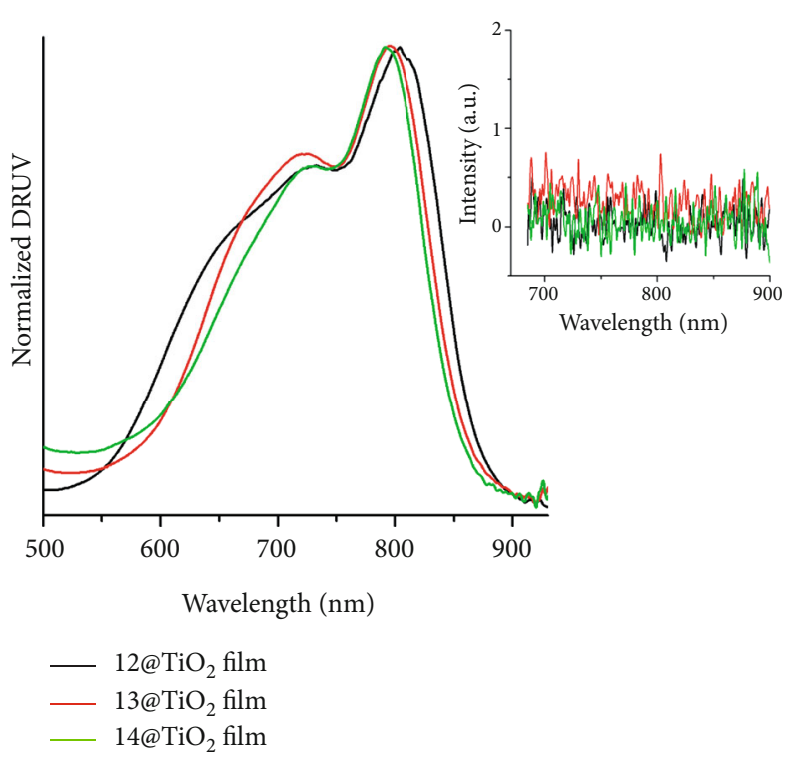

(a)

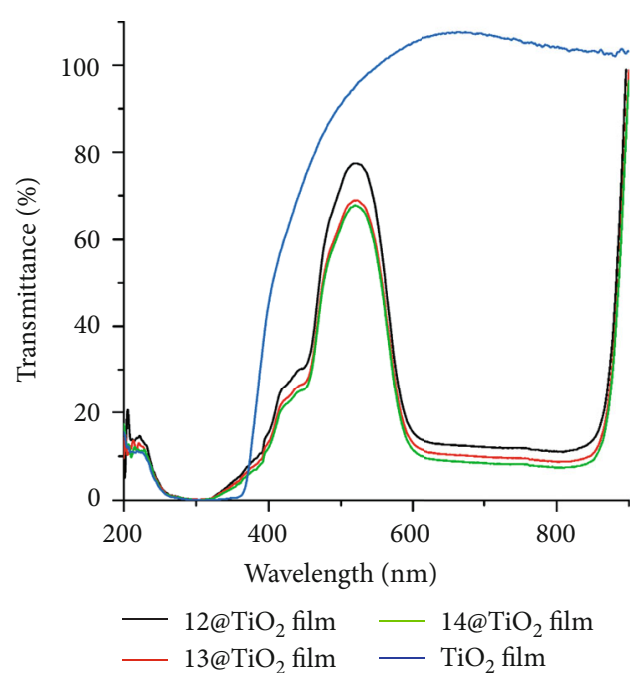

(b)

Figure 2: Normalized $(\mathrm{a}-\mathrm{c})$ Vis-NIR and $(\mathrm{d}-\mathrm{f})$ fluorescence emission spectra in solution $\left(10^{-6} \mathrm{M}\right)$ of the carboxy heptamethine dyes $12-14$.

TABLE 2: Photophysical data of compounds 12-14 in solution, where $\lambda_{\mathrm{abs}}$ and $\lambda_{\mathrm{em}}$ are the absorption and emission wavelengths, respectively; $\varepsilon$ $\left(\times 10^{5}\right)$ is the molar absorptivity coefficient, $\Delta \lambda_{\mathrm{ST}}$ is the Stokes shift; and $E_{g}^{\text {opt }}$ is the optical bandgap.

\begin{tabular}{ccccccc}
\hline Dye & Solvent & $\lambda_{\text {abs }}(\mathrm{nm})$ & $\varepsilon\left(\mathrm{M}^{-1} \cdot \mathrm{cm}^{-1}\right)$ & $\lambda_{\text {em }}(\mathrm{nm})$ & $\Delta \lambda_{\mathrm{ST}}\left(\mathrm{nm} / \mathrm{cm}^{-1}\right)$ & $8 / 125$ \\
\hline \multirow{2}{*}{12} & $\mathrm{DMF}$ & 797 & 1.13 & 805 & 793 & $6 / 96$ \\
& $\mathrm{CH}_{3} \mathrm{OH}$ & 787 & 2.46 & 1.09 & 800 & $4 / 63$ \\
13 & $\mathrm{DMF}$ & 796 & 3.16 & 794 & $9 / 144$ & 1.48 \\
& $\mathrm{CH}_{3} \mathrm{OH}$ & 785 & 1.39 & 805 & $8 / 125$ \\
14 & $\mathrm{DMF}$ & 797 & 3.22 & 793 & $9 / 145$ \\
& $\mathrm{CH}_{3} \mathrm{OH}$ & 784 & & & 1.45 \\
\hline
\end{tabular}

by van der Waals interactions, hydrogen bonds, or hydrophobic interactions $[16,19]$.

In order to better characterize their photophysics, emission spectra were obtained from both absorption bands $(\sim 720 \mathrm{~nm}$ and $\sim 800 \mathrm{~nm}$ ) indicating similar location with different intensities, as expected by Kasha's rule (Figures S28-S30). In addition, the respective excitation spectra (Figures S31-S33) also presented a similar shape and location if compared to the UV-Vis spectra, which corroborates with the expected $\mathrm{S}_{0} \longrightarrow \mathrm{S}_{2}$ for the absorption band around $720 \mathrm{~nm}$.

The fluorescence emission spectra of compounds 12-14 present emission maxima located between 793 and $805 \mathrm{~nm}$. As expected, very small Stokes shifts were computed for these compounds (below $10 \mathrm{~nm}$ experimentally; $25 \mathrm{~nm}$ theoretically) due to their symmetrical nature and rigidity. These small Stokes shifts are supported by the very small change in the molecular geometries going from the ground to the first excited state and by the localized character of this ${ }^{1} p p *$ transition.

The photophysical behavior of compounds 12-14 was also evaluated in the solid state by absorption and fluorescence emission spectra (Figure 3), for the dyes adsorbed on the $\mathrm{TiO}_{2}$ mesoporous films (guest-host system). This investigation is of great importance to evaluate the potential of these compounds for application in dye-sensitized solar cells. The studied compounds showed outstanding adsorption on $\mathrm{TiO}_{2}$, which can be justified by the presence of carboxyl moieties, known as good anchoring groups [38]. A very broad absorption band with maxima located in the near-infrared region is observed between 794 and $804 \mathrm{~nm}$. This absorption band presents the full width at half maximum (FWHM) around $180 \mathrm{~nm} \mathrm{(213} \mathrm{nm} \mathrm{(12),} 185 \mathrm{~nm} \mathrm{(13),} \mathrm{and} 167 \mathrm{~nm}$ (14)) when compared to the results in methanol $(53 \mathrm{~nm}$ (12), $51 \mathrm{~nm}$ (13), and $50 \mathrm{~nm}$ (14)) or DMF (112 nm (12), $105 \mathrm{~nm}$ (13), and $119 \mathrm{~nm}$ (14)) solution. Additionally, an intense blue-shifted band was found between 724 and $731 \mathrm{~nm}$, different than what was observed in the solution and probably related to the formation of type $\mathrm{H}$-aggregates, favored by a large number of molecules on the surface of $\mathrm{TiO}_{2}$. It is worth mentioning that the formation of $\mathrm{H}$ aggregates can be a major disadvantage when the application to solar cells is envisaged. The strong aggregation of these molecules can lead to a drastic decrease of electron injection in the $\mathrm{TiO}_{2}$ conduction band, reducing the conversion efficiency of solar cells [20]. However, despite the presence of such aggregates, the broad absorption band in the solidstate is very important for sensitization of semiconductors and subsequent application in solar cells sensitized by 

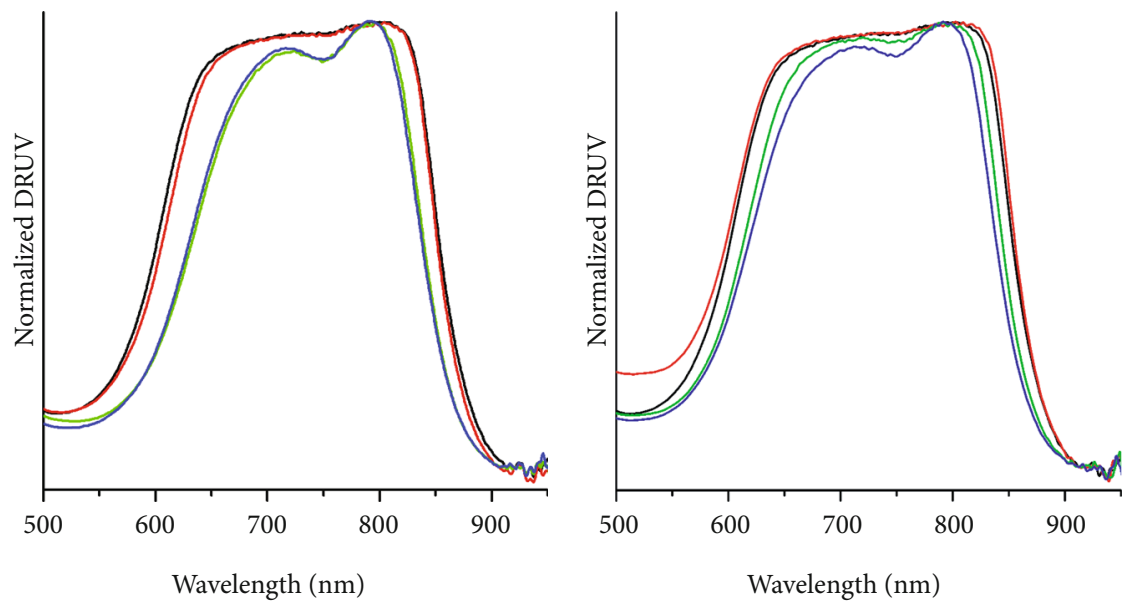

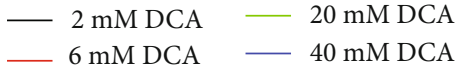

(a)

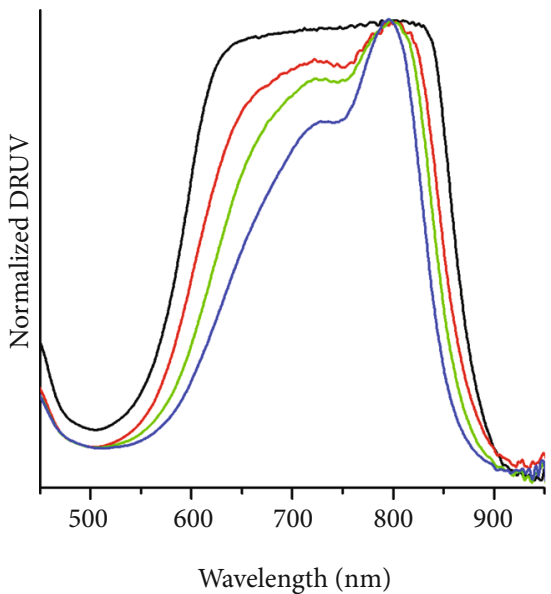

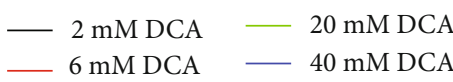

(c)

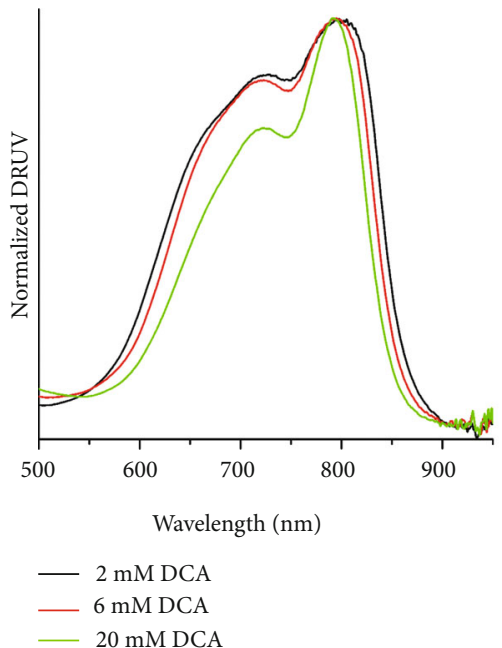

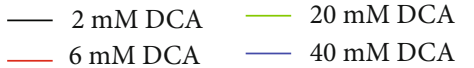

(b)

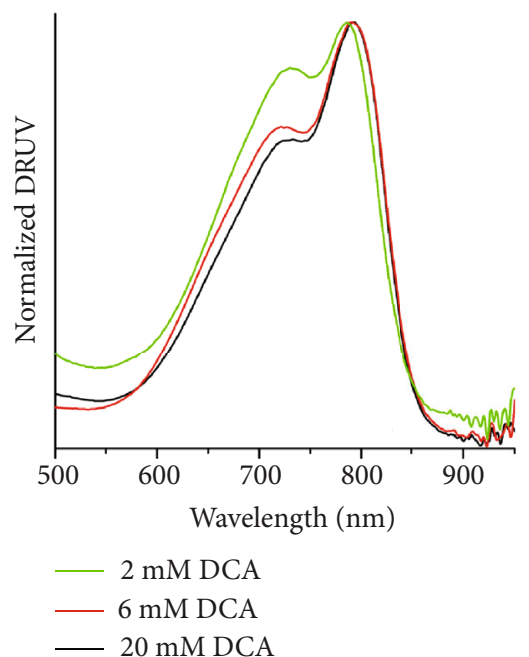

(d)

(e)

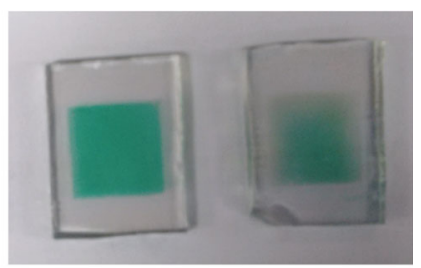

FIgURe 3: (a) Normalized UV-Vis spectra in the solid state of compounds 12-14 adsorbed on $\mathrm{TiO}_{2}$ (powder) and (b) transmittance spectra of $\mathrm{TiO}_{2}$ film adsorbed with compound 13. The inset presents the fluorescence emission $\left(\lambda_{\text {exc }}=794 \mathrm{~nm}\right)$ investigation of these samples. 
organic dyes, since a broader absorption range results in an optimized photon collection and, consequently, in a greater generation of electron-hole pairs and higher efficiency in converting light into electrical current. Additionally, the emission spectra of compounds 12-14 show a complete fluorescence quenching (Figure 3, insert).

The transmittance spectra of $\mathrm{TiO}_{2}$ films sensitized by compounds 12-14 are also presented in Figure 3, where it is possible to observe the very low transmittance $(\sim 12 \%)$ in the region between 540 and $895 \mathrm{~nm}$, followed by the increase of the transmittance (up to 80\%) between 485 and $535 \mathrm{~nm}$, which can be related once again to the significant adsorption of these compounds on $\mathrm{TiO}_{2}$. Based on the solid-state results presented so far, it can be observed that the $\mathrm{H}$-aggregates are present, which can impair the efficiency of solar cells prepared with these compounds. To minimize the formation of $\mathrm{H}$-aggregates of compounds 12-14 on the surface of $\mathrm{TiO}_{2}$, a coadsorption study was performed with deoxycholic acid (DCA). DCA is sterically bulky, and for this reason, it is expected to hinder the $\mathrm{H}$-aggregation formation [20]. In this way, five different methodologies of adsorption on the mesoporous $\mathrm{TiO}_{2}$ films were proposed and evaluated using compound 13 as a model (Table 1). In this study, the aggregation effect was evaluated taking the intensity of the $\mathrm{H}$-aggregate absorption band located around $700 \mathrm{~nm}$ into account (Figure 1). It is worth mentioning that, based on the original data (not shown, see supplementary material Figures S34), signal saturation was discarded in Figures 1(a) and Figures 1(b) (2 and $6 \mathrm{mM} \mathrm{DCA}$ ) and Figure 1(c) ( $2 \mathrm{mM}$ DCA). This result clearly indicates that aggregation influences the shape and intensity of the solid-state UV-Vis spectra of these compounds. Additionally, based on the absorbance intensities, a higher dye loading could be obtained at $20 \mathrm{mM}$ DCA for \#1, \#2, \#4, and \#5 and $6 \mathrm{mM}$ DCA for \#3.

DRUV spectra obtained from the first used methodology (\#1) show that a small concentration of coadsorber $(2 \mathrm{mM})$ results in the formation of an absorption band located at higher energy, attributed to $\mathrm{H}$-aggregates, which present the same intensity of the absorption band related to the monomeric form related to the cyanine dye (Figure 1(a)). A similar result was observed using $6 \mathrm{mM}$ DCA. At higher DCA concentrations $(20 \mathrm{mM}$ and $40 \mathrm{mM})$, a significant decrease in the intensity of the absorption band related to $\mathrm{H}$-aggregates is observed, indicating more efficient aggregation suppression. Due to the strong interaction between these cyanine dyes, probably by $\pi$-stacking, the total suppression of the aggregation was not observed at the studied DCA concentrations. By comparing Figures 1(a) and 1(b), the evolution of absorption spectra along with the increase in DCA concentration is similar for methods \#1 and \#2, and changes in the $\mathrm{TiO}_{2}$ temperature during adsorption is found to not play a significant role in the aggregation suppression. Based on these results, the adsorption temperature was fixed at $22^{\circ} \mathrm{C}$ to the next methodologies. In methodology \#3, the influence of the adsorption time on the formation of aggregates is clearly observed by the significant decrease in the absorption band at $724 \mathrm{~nm}$ (Figure 1(c)). Based on studies described in the literature about the formation of $\mathrm{H}$ -

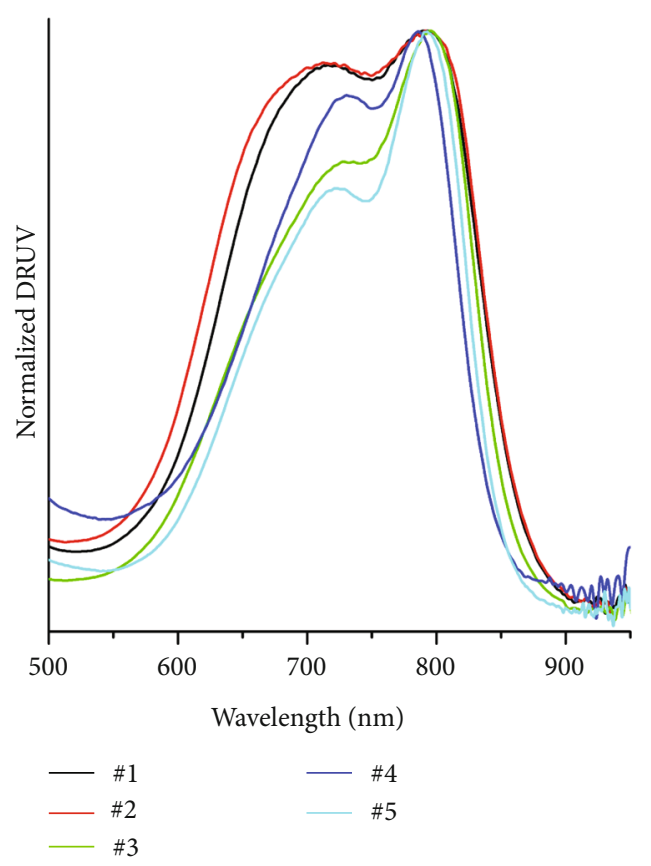

FIgURE 4: Normalized solid-state absorption spectra of dye 13 obtained from the different adsorption methodologies (\#1-\#5), where \#1: dye concentration- $5.0 \mathrm{mM}$, DCA concentrations-20 or $40 \mathrm{mM}, \mathrm{TiO}_{2}$ temperature $-80^{\circ} \mathrm{C}$, and adsorption time- $24 \mathrm{~h}$; \#2: dye concentration- $5.0 \mathrm{mM}$, DCA concentration- $40 \mathrm{mM}$, $\mathrm{TiO}_{2}$ temperature $-22^{\circ} \mathrm{C}$, and adsorption time-24h; \#3: dye concentration-5.0 mM, DCA concentration- $40 \mathrm{mM}, \quad \mathrm{TiO}_{2}$ temperature $-22^{\circ} \mathrm{C}$, and adsorption time-1 $\mathrm{h}$; \#4: dye concentration $-0.1 \mathrm{mM}, \quad$ DCA concentration- $20 \mathrm{mM}, \quad \mathrm{TiO}_{2}$ temperature $-22^{\circ} \mathrm{C}$, and adsorption time $-1 \mathrm{~h}$; \#5: first step: DCA concentration $-20 \mathrm{mM}$ and second step: dye concentration $-0.1 \mathrm{mM}$, $\mathrm{TiO}_{2}$ temperature $-22^{\circ} \mathrm{C}$, and adsorption time $-1 \mathrm{~h}$.

aggregates in heptamethine cyanines $[16,20,22]$, the concentration of 13 was fixed at $0.1 \mathrm{mM}$. Due to the low dye loading on $\mathrm{TiO}_{2}$ when using the reduced concentration of cyanine $(0.1 \mathrm{mM})$ and $40 \mathrm{mM}$ of DCA, for methodologies \#4 and \#5, only solutions containing 2, 6, and $20 \mathrm{mM}$ DCA were studied. Figure 1(d) shows this unlike what was earlier observed for \#1, \#2, and $3 \#$ when using methodology \#4. DCA concentration plays a very important role in the formation of $\mathrm{H}$-aggregates, where the lowest aggregate formation was observed using $20 \mathrm{mM}$ DCA. To reduce the competition between the cyanine dye and DCA molecules for active sites in the $\mathrm{TiO}_{2}$ surface, a fifth methodology was proposed. As one can observe, the DRUV spectra from \#5 using 2 and $6 \mathrm{mM}$ of DCA are similar. However, at higher concentrations of DCA $(20 \mathrm{mM})$, the decrease in absorption band related to the $\mathrm{H}$-aggregates is very significant. These results show that a good compromise between the lowest proportion of the $\mathrm{H}$ aggregate and the best homogeneity of sensitization was obtained using one hour of adsorption, $0.1 \mathrm{mM}$ dye concentration, and $20 \mathrm{mM}$ DCA concentration (Figure 4).

\subsection{Theoretical Calculations}

3.3.1. Natural Transition Orbitals and Structural Parameters. From the theoretical calculations, it was possible to confirm 

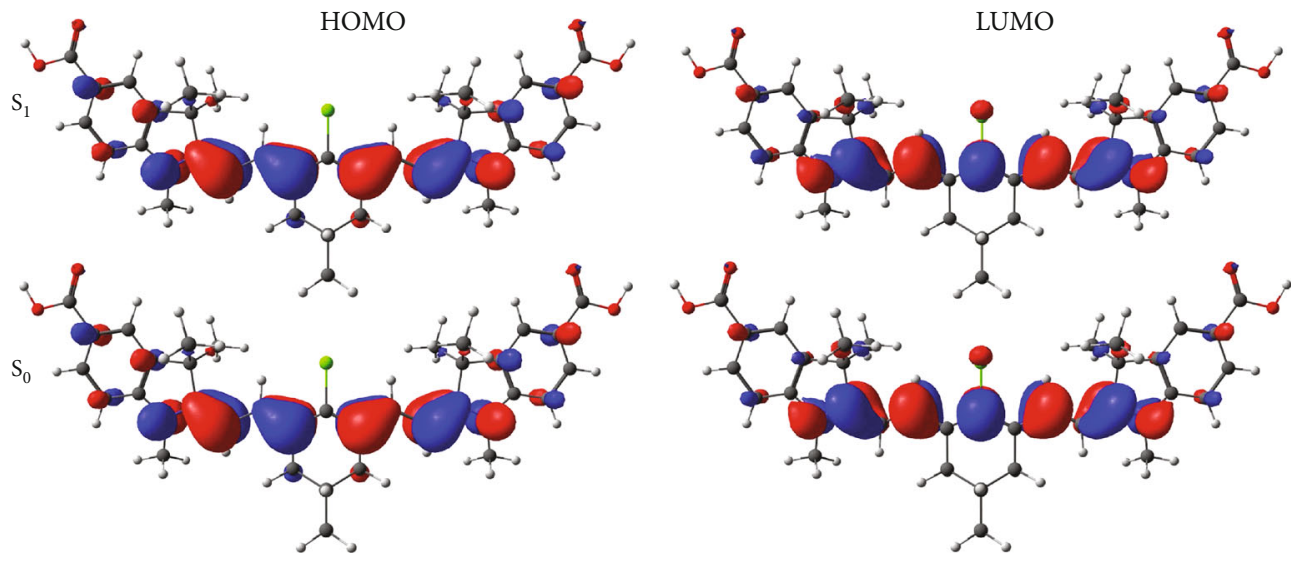

Figure 5: Natural transition orbitals for the vertical transitions $S_{0} \longrightarrow S_{1}$ and $S_{1} \longrightarrow S_{0}$ involving the ground and first excited states of cyanine 12 in $\mathrm{PCM} / \mathrm{methanol.}$

that the lowest-energy electronic transition $\mathrm{S}_{0} \longrightarrow \mathrm{S}_{1}$ is dominated by HOMO to LUMO and has a ${ }^{1} \pi \pi *$ character, as depicted in Figure 5 for cyanine 12. The natural transition orbitals, NTOs, associated to this transition show that the pair hole/particle, which, in this case, is identical to HOMO (hole) and LUMO (particle), is mainly delocalized in the central part of the molecule, comprised between the two heterocyclic rings. Similar behavior was observed for the other studied cyanines (Figures S24-S25). A large oscillator strength (Table S1) and strong overlap between the frontier orbitals involved in this transition were also observed, suggesting an electronic excitation of localized character. Table S1 also shows absorption and emission maxima wavelength obtained with TD-DFT. No significant differences on these values were observed by changing the alkyl group attached to the central ring, in accordance with the experimental results. This result is expected since the change in the $\mathrm{R}$ groups does not have a significant impact in the molecular geometry and the $\mathrm{R}$ group is not directly involved in the lowest-energy electronic transition. Yet, no significant change in the vertical electronic transitions was observed by changing the solvent from methanol to DMF, which was expected since both solvents have similar dielectric constants and the PCM model is not able to describe the effect of hydrogen interactions. In fact, the experimental results confirmed that the protic solvent has a very small effect on the UV-Vis spectra in the liquid phase. It is worth mentioning that the vertical transitions obtained with M06-2X functional are within the average margin of error obtained for cyanine dyes computed with TD-DFT [26]. For the studied cyanines, an average error of $0.13 \mathrm{eV}$ and $0.08 \mathrm{eV}$ was found for the $S_{0}$ and $S_{1}$, respectively, when compared to the experimental values.

As can be seen in Figure 6 using compound 13 as a model, $S_{0}$ and $S_{1}$ optimized geometries are planar and symmetrical. For the other cyanines studied, see Figures S26S27. Although very small, the main differences between the $S_{0}$ and $S_{1}$ are observed in the alternated single-double bond lengths, due to the character of the electronic transition. Since this transition does not involve the carbonyl group, the $\mathrm{C}-\mathrm{O}$ bond length is preserved. The very mild difference between these two states is also reflected in the subtle change in the dipole moment (Table S1), supporting the localized character of the transition and the lack of solvent effect on the lowest electronic transitions.

The structural parameters for dyes 12-14 are listed in Table S3. Apart from <C10C9C20C21, which involves a sp ${ }^{3}$ carbon atom, all the remaining dihedral angles listed in the table are nearly 180 degrees, meaning that the molecules present a high degree of planarity in both $S_{0}$ and $S_{1}$ states. Yet, the molecules present a high degree of delocalization through its $\pi$ system, as evidenced by the bond length pattern in the conjugated system. Thus, the donor, acceptor groups, $\pi$-bridge, and anchor groups $(-\mathrm{COOH})$ are coplanar, which would enhance the delocalization of $\pi$ electrons and, thus, the intramolecular electron transfer through it. As can be seen from the frontier molecular orbital plots and confirmed by the ESP maps (Figure 7), the $S_{0}$ to $S_{1}$ excitation has a local character (which is reflected in the bond length pattern change), without any evidence of charge transfer.

3.3.2. Energy Levels and Charge Separation. The calculated energy levels of HOMO, LUMO, and band gap are presented in Table S2. The energy level diagram is presented in Figure 8. It is worth noticing that the calculated HOMO and LUMO energy levels are very sensitive to the method (basis set and functional) and can be very inaccurate due to the electron self-interaction error in DFT, providing LUMO energies with nonphysical meaning. A more accurate way to obtain HOMO-LUMO energies is using the vertical ionization potential (IP) and electron affinity (EA). This procedure is known as the $\triangle \mathrm{SCF}$ approach [39]. In this approach, the HOMO and LUMO energies are obtained using the electronic energies of the neutral $(\mathrm{M})$, cation $\left(\mathrm{M}^{+}\right)$, and anion $\left(\mathrm{M}^{-}\right)$according to the following [40]:

$$
\begin{gathered}
\mathrm{IP}=E\left(M^{+}\right)-E(M), \\
\mathrm{EA}=E(M)-E\left(M^{-}\right) .
\end{gathered}
$$




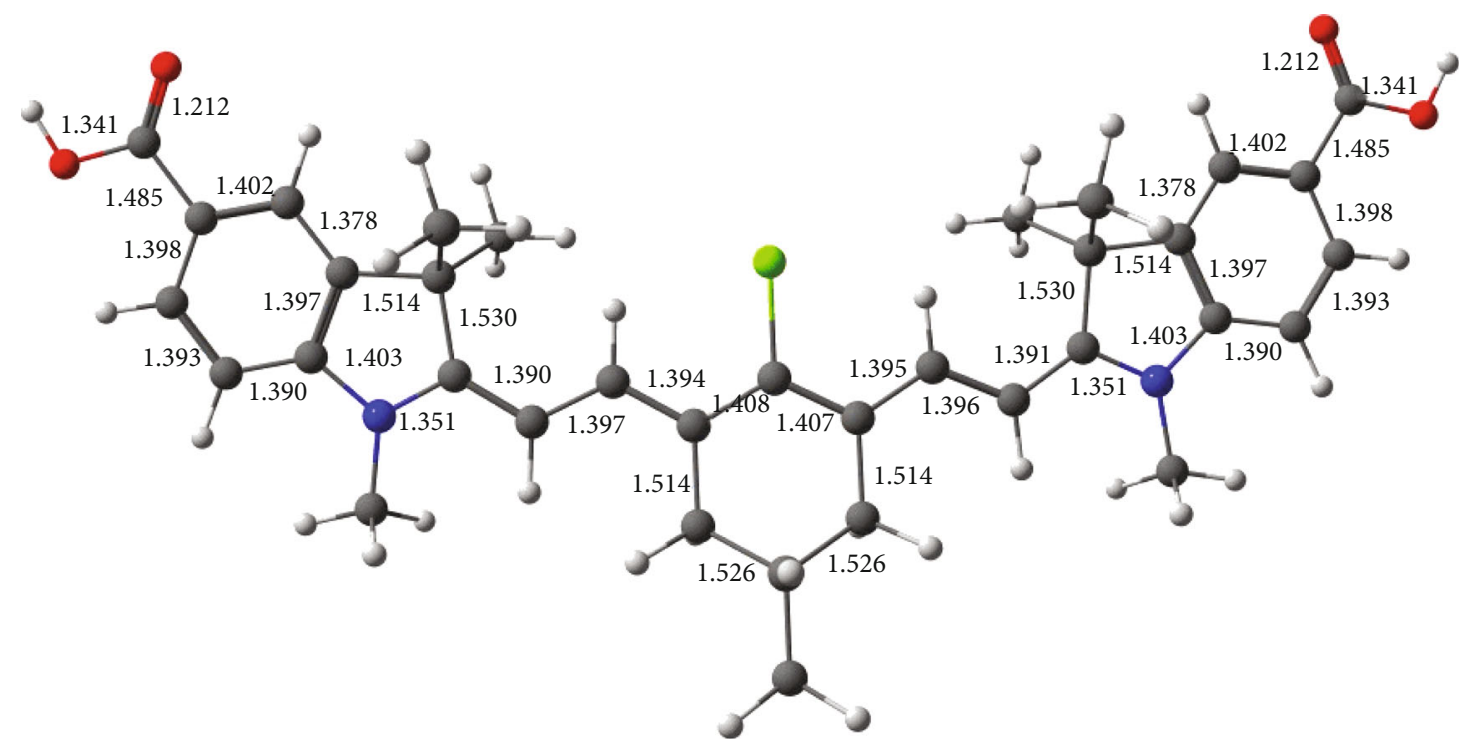

(a)
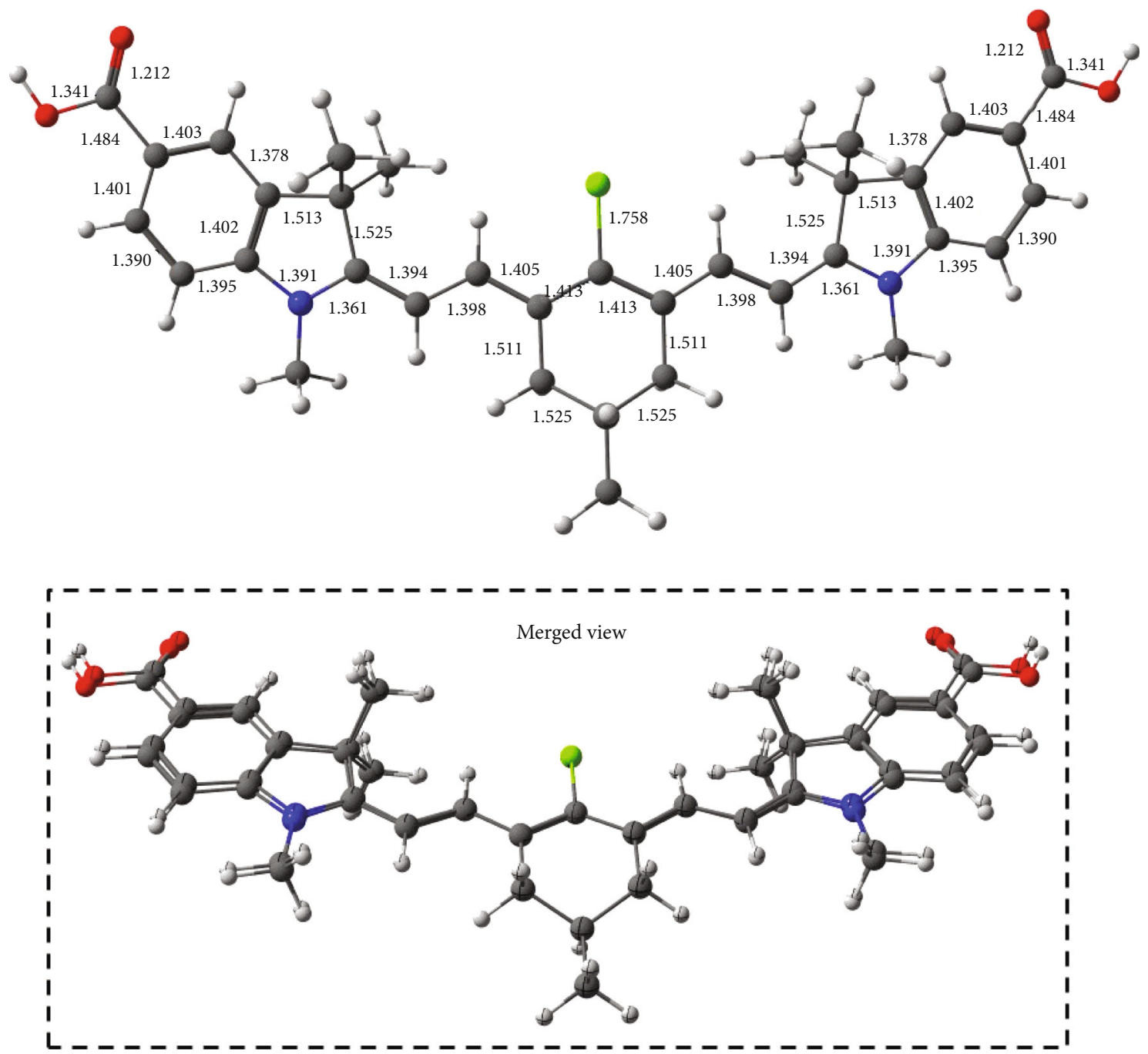

(b)

Figure 6: Optimized geometries for the (a) ground and (b) first excited states of cyanine 13 in PCM/methanol. A merged view $\left(\mathrm{S}_{0}\right.$ and $\left.\mathrm{S}_{1}\right)$ was presented for comparison. 


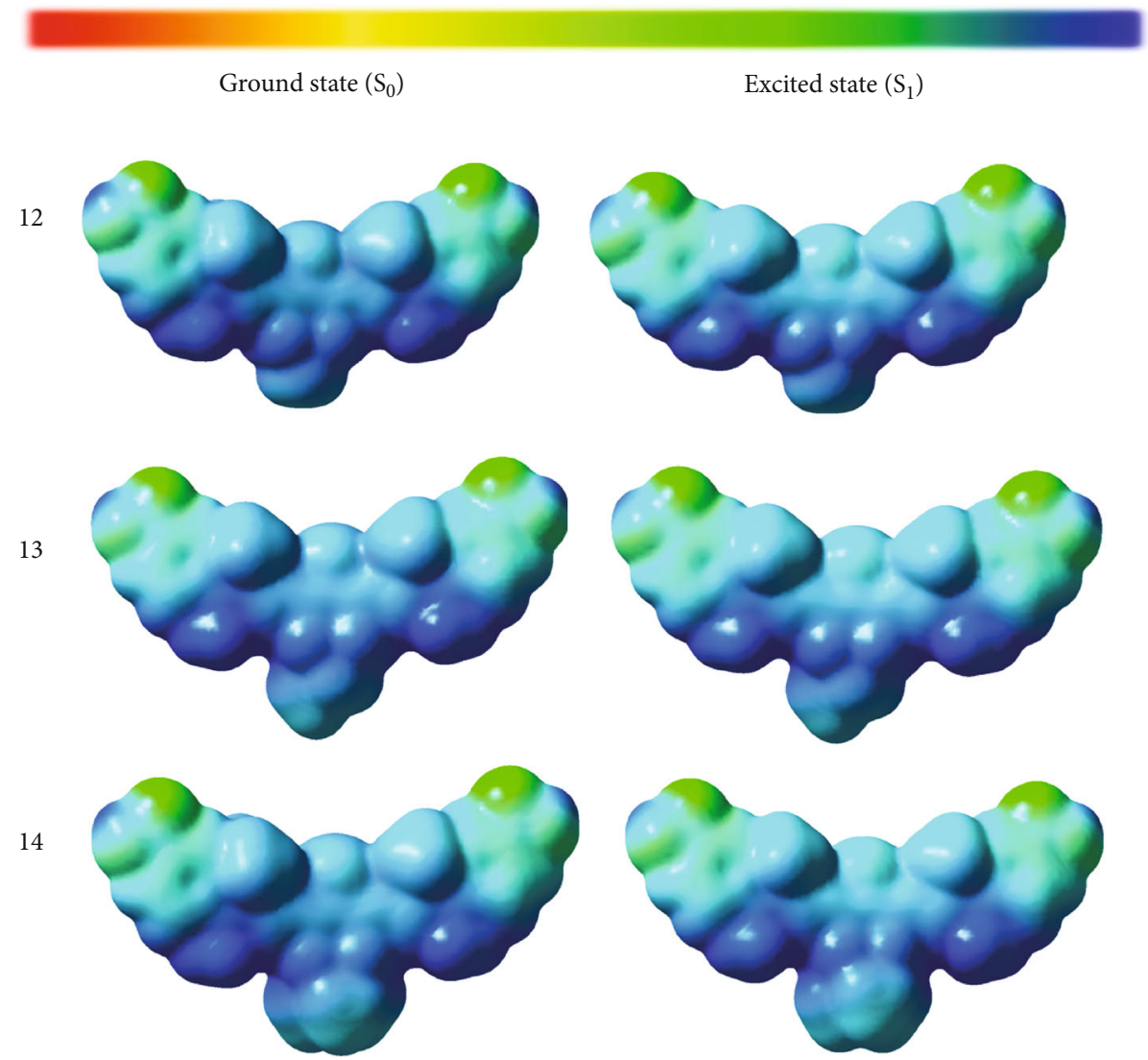

Figure 7: Electrostatic potential surfaces computed at M06-2X/6-311+G(d,p)//M06-2X/6-31G(d,p) in PCM/methanol for the dyes 12-14 in the ground and excited states.

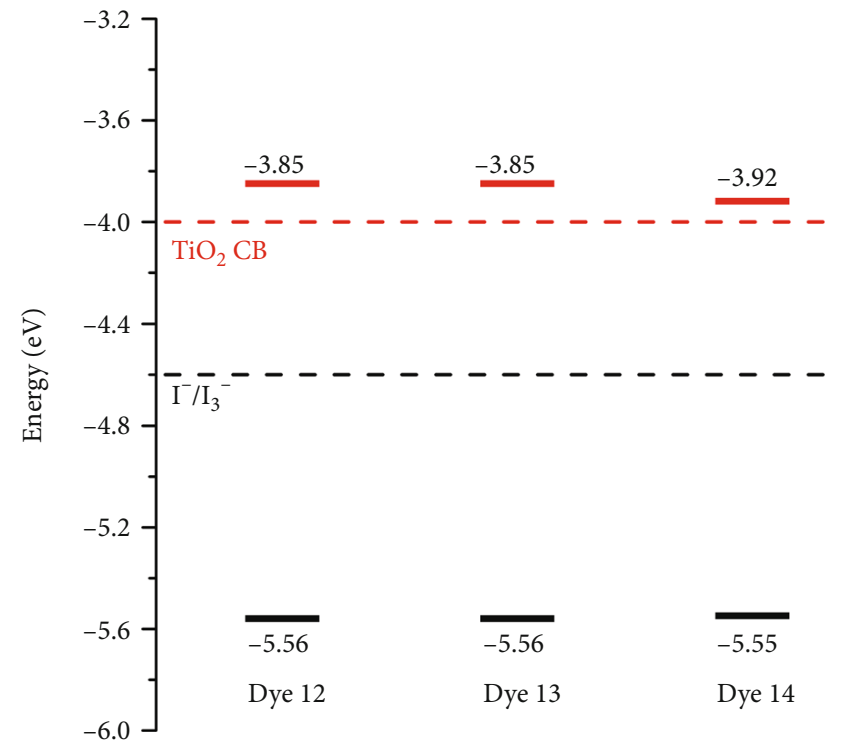

FIgURE 8: Energy level diagram. $\triangle \mathrm{SCF} \mathrm{HOMO}$ and LUMO energies (in $\mathrm{eV}$ ) computed at M06-2X/6-311+G(d,p)//M06-2X/6-31G(d,p) in $\mathrm{PCM} / \mathrm{methanol}$.

Thus, the IP and EA are directly related to HOMO and LUMO energies by Koopmanns' theorem through the relations $\mathrm{IP}=-E_{\mathrm{HOMO}}$ and $\mathrm{EA}=-E_{\mathrm{LUMO}}$. Due to the
TABLE 3: Electrochemical properties of compounds 12-14, where $E_{\text {oxi }}^{\text {onset }}$ is the onset potential of oxidation, $E_{\text {red }}^{\text {onset }}$ is the onset potential of reduction, IP (HOMO) is the ionization potential, EA (LUMO) is the electron affinity, and $E_{\text {gap }}^{\text {ele }}$ is the electrochemical bandgap.

\begin{tabular}{lccc}
\hline & 12 & 13 & 14 \\
\hline$E_{\text {oxi }}^{\text {onset }}(\mathrm{V})$ & 0.360 & 0.350 & 0.480 \\
$E_{\text {red }}^{\text {onset }}(\mathrm{V})$ & -0.51 & -0.55 & -0.54 \\
$\mathrm{IP}(\mathrm{HOMO})(\mathrm{eV})^{\mathrm{a}}$ & -4.80 & -4.79 & -4.92 \\
$\mathrm{EA}(\mathrm{LUMO})(\mathrm{eV})^{\mathrm{b}}$ & -3.93 & -3.89 & -3.90 \\
$E_{\text {gap }}^{\text {ele }}(\mathrm{eV})$ & 0.87 & 0.90 & 1.02 \\
${ }^{\mathrm{a}}$ Calculated using Equation $(1) ;{ }^{\mathrm{b}}$ calculated using Equation (2). &
\end{tabular}

approximations in the exchange-correlation functionals, this theorem can be no longer valid at the DFT level, i.e., the IP and EA are not truly equivalent to the HOMO and LUMO Kohn-Sham orbital energies, respectively. Therefore, in this work, the band gap is calculated taking the difference between EA and IP. Using this procedure, we have obtained a very good agreement with the optical gap $\left(\Delta_{\text {opt }}\right)$, i.e., the lowest vertical excitation calculated by TDDFT. On the other hand, the energy gap is overestimated when determined directly from HOMO and LUMO energies provided by DFT calculations (Kohn-Sham gap). This discrepancy suggests that a simple estimate of the 


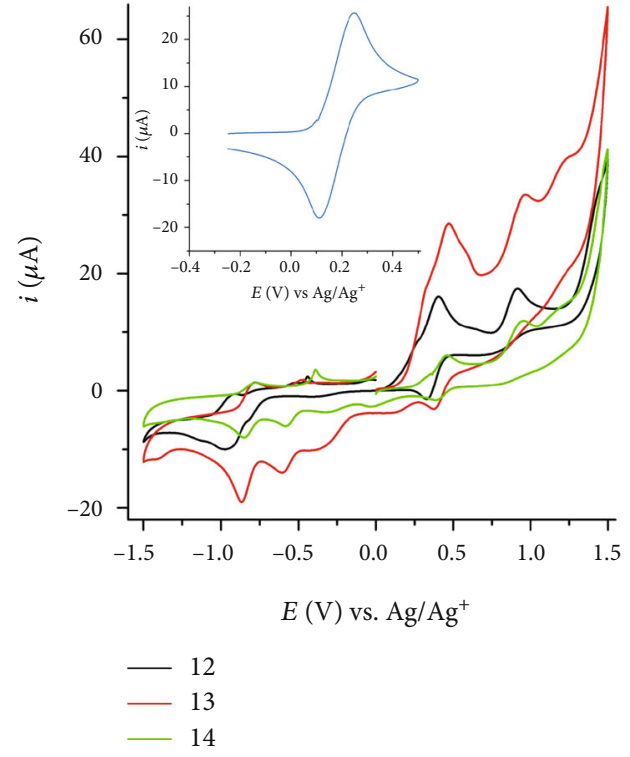

(a)

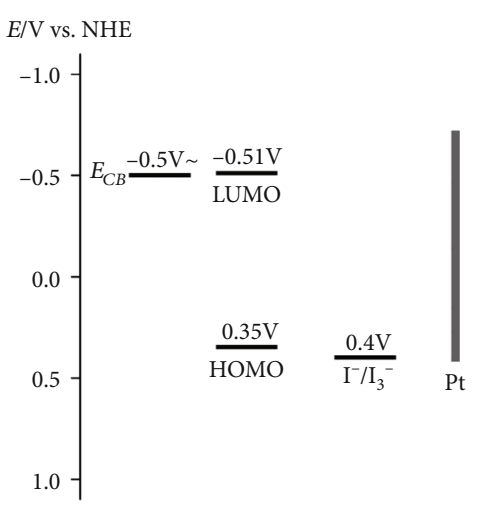

FIgure 9: (a) Cyclic voltammogram of a glassy carbon electrode in $0.1 \mathrm{TBAPF}_{6} / \mathrm{CH}_{2} \mathrm{Cl}_{2}$ at $100 \mathrm{mV} \cdot \mathrm{s}^{-1}$ of $\mathrm{cyanine}$ dyes $12-14$. Inset: voltammogram of ferrocene. (b) Energy diagram of $\mathrm{TiO}_{2}$, cyanine 13, and the electrolyte $\mathrm{I}^{-} / \mathrm{I}_{3}^{-}$.

excited state energy using the Kohn-Sham eigenvalues for HOMO and LUMO is not appropriate for dyes 12-14.

Another way to obtain the energy levels is by computing the excited state (corresponding to the LUMO energy) as a sum between the ground state energy (HOMO energy) and the optical gap $\left(\Delta_{\text {opt }}\right)$ according to the following expression [41, 42]:

$$
E_{\text {dye } *}=E_{\text {dye }}+\Delta_{\text {opt }} .
$$

For dyes 12-14, the optical gap is equal to $1.70 \mathrm{eV}$. Thus, following the expression above, the calculated LUMO energy is $-4.76 \mathrm{eV}$ (see Table S2). Although the calculated energy gaps are bigger than the experimental values provided in Table 3, a very good agreement is observed for the EA energies. These LUMO energies are slightly above the experimental anatase conduction band (CB) minimum $(-4.00 \mathrm{eV})$ [43]. This would lead to the electron injection from excited dye molecules into the $\mathrm{TiO}_{2} \mathrm{CB}$. The calculated and experimental values obtained for the IP (HOMO energies) are more negative than the $\mathrm{I}^{-} / \mathrm{I}_{3}{ }^{-}$redox potential $(-4.6 \mathrm{eV})$ [44]. Thus, theoretically the relative position of HOMO and LUMO energy level in the dyes 1214 would ensure an injection of the electrons in the $\mathrm{TiO}_{2} \mathrm{CB}$ and efficient dye regeneration. The similar energy gaps and HOMO-LUMO energies indicates a similar electroninjection and regeneration for the three dyes considered in this work.

3.3.3. Light Harvesting Efficiency (LHE). Light harvesting efficiency (LHE) is another important factor that determines the efficiency of a DSSC. It can be determined by [45]

$$
\mathrm{LHE}=1-10^{-A}=1-10^{-f}
$$

where $f$ is the oscillator strength corresponding to the absorption energy of the dye. From this relation, is clear that higher oscillator strength implies larger LHE values and higher photocurrent. The LHE values obtained from TD-DFT calculation are presented in Table S2. As a consequence of the larger oscillator strengths, LHE values are very close to the unity, indicating an efficient photocurrent.

3.4. Electrochemical Characterization. To determine experimentally the relative position of the energy levels of the studied cyanine dyes 12-14, cyclic voltammeters were performed in the solution (Figure 9). The relevant data from this investigation are summarized in Table 3. The HOMO and LUMO energy levels of 12-14 were determined by the ionization potential (IP) and electron affinity (EA), respectively, which could be correlated with electrochemical processes accessed by $\mathrm{CV}$, where the potentials were standardized with a $\mathrm{Fc} / \mathrm{Fc}^{+}$ couple. The IP and EA values were calculated using the following empirical equations [46]:

$$
\begin{aligned}
\mathrm{IP} & =-\left(E_{\text {oxi }}^{\text {onset }}+4.44\right) \mathrm{eV}, \\
\mathrm{EA} & =-\left(\mathrm{E}_{\text {red }}^{\text {onset }}+4.44\right) \mathrm{eV},
\end{aligned}
$$

where $E_{\text {oxi }}^{\text {onset }}$ and $E_{\text {red }}^{\text {onset }}$ are the oxidation and reduction onset potentials, respectively.

Through the comparative analysis of the voltammograms (Figure $7(\mathrm{a})$ ) and the data presented in Table 3, it is possible to observe that these results are not satisfactory since, considering the small difference between the averaged values of their reduction potential $(\sim-0.53 \mathrm{~V})$ and the edge value of the $\mathrm{TiO}_{2}$ conduction band $(0.5 \mathrm{~V})$, recombination processes can be favored. Based on the oxidation potential values obtained for compounds 12-14, it can be observed that they are not favorable for an efficient process of dye regeneration 


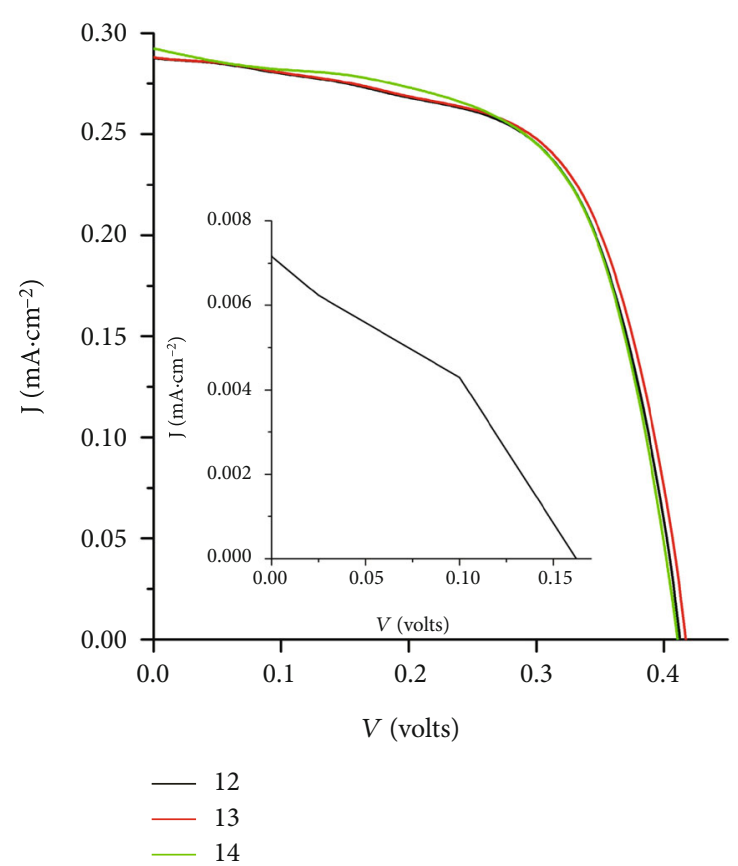

FIGURE 10: $J$ vs. $V$ curves from DSSCs sensitized with cyanines 12-14. The inset shows the $J$ vs $V$ curve from the device assembled with 13 without the coadsorption of DCA.

by the electrolyte when composed of an $I^{3-} / I^{-}(0.4 \mathrm{~V})$ redox pair (Figure 9(b)).

3.5. Photoelectrochemical Characterization. Photophysical studies presented in Figure 5 have shown that method \#5 was the most efficient approach allowing high dye loading and low $\mathrm{H}$-aggregation; hence, DSSCs were assembled using this method to absorb compounds 12,13, and 14 and to coadsorb DCA (Figure 10). For comparison, a DSSC using compound 13 was assembled without DCA (Figure 10, insert). One can observe that the compounds 12, 13, and 14 result in DSSCs with similar electrical behaviour and efficiency (Table 4), which is expected once the compounds present very similar structures (Scheme 1). The results also show that the methyl, ethyl, and tert-butyl groups present on the cycloalkene do not affect significantly either dye loading or dye aggregation. Indeed, the presence of DCA as a coadsorber has efficiently affected the electrical parameters and the efficiency of the DSSCs. The short circuit current density (Jsc) $\left(0.28 \mathrm{~mA} \cdot \mathrm{cm}^{-2}\right)$ and conversion efficiency $(\eta)$ $(0.07 \%)$ values, although low, show a significant improvement if compared to those obtained for the devices assembled without the coadsorber $\left(0.0072 \mathrm{~mA} \cdot \mathrm{cm}^{-2}\right)$. The gain in DSSC performance is related to the decreased formation of $\mathrm{H}$ aggregates, by the simultaneous use of deoxycholic acid as a coadditive, as observed in Figure 5 [16, 20, 22].

The low values of Jsc and $\eta$ can be attributed to two main factors: (i) low dye concentration on the $\mathrm{TiO}_{2}$ surface and (ii) the similar oxidation potential values of compounds 12-14 obtained for the edge of the $\mathrm{TiO}_{2}$ conduction band, this latter being a facilitator for recombination processes. As one can observe, the introduction of DCA dramatically decreases
TABLE 4: Electrical parameters and efficiency of solar cells sensitized with compounds $12-14$, where Jsc is the short circuit current density $\left(\mathrm{mA} \cdot \mathrm{cm}^{2}\right)$, Voc is the open circuit voltage $(\mathrm{V}), \mathrm{FF}$ is the fill factor (\%), and $\eta$ is the conversion efficiency (\%). The measurements were carried out under one sun $\left(100 \mathrm{~mW} \cdot \mathrm{cm}^{-2}\right)$ using AM1.5 filter.

\begin{tabular}{lccccc}
\hline Device & Compound & Jsc & Voc & FF & $\eta$ \\
\hline 1 & 12 & 0.28 & 0.41 & 64 & 0.07 \\
2 & 13 & 0.28 & 0.41 & 64 & 0.07 \\
3 & 14 & 0.29 & 0.41 & 62 & 0.07 \\
$4^{\text {a }}$ & 13 & $7.2 \times 10^{-3}$ & 0.17 & 32 & $0.02 \times 10^{-3}$ \\
\hline
\end{tabular}

${ }^{\mathrm{a} W i t h o u t ~ D C A . ~}$

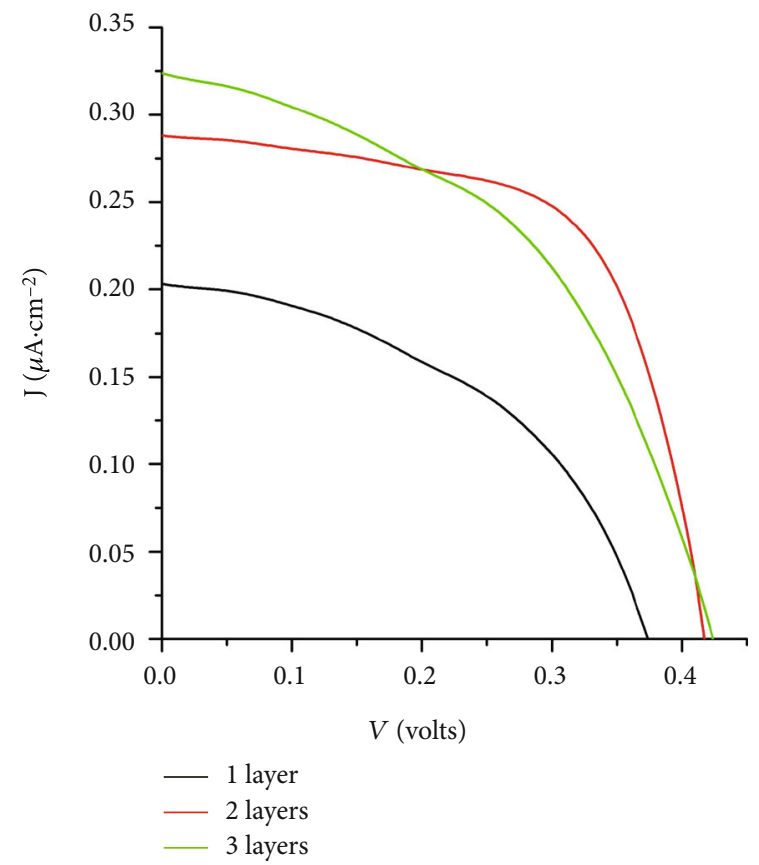

Figure 11: Plot $J$ vs $V$ of devices at different $\mathrm{TiO}_{2}$ film thicknesses (black) $5 \mu \mathrm{m}$ (1 layer), (red) $12 \mu \mathrm{m}$ (2 layers), and (green) $16 \mu \mathrm{m}$ (3 layers) prepared by methodology \#5.

resistance in series and increases resistance in parallel, which is an important finding for the present system once both $R_{S}$ and $\mathrm{R}_{\mathrm{P}}$ contribute to fill factor degradation [47].

The influence of the $\mathrm{TiO}_{2}$ film thickness on the efficiency of the devices was also evaluated. To carry out this study, devices with $\mathrm{TiO}_{2}$ films with different thicknesses $(5,12$, and 16 micrometers) were assembled. The scanning electron microscopy images show that the average thickness of the films already sintered was about $5 \mu \mathrm{m}$ for 1 layer, $12 \mu \mathrm{m}$ for 2 layers, and $16 \mu \mathrm{m}$ for 3 applied layers of colloidal solution of $\mathrm{TiO}_{2}$ nanoparticles (Figures S35). Figure 11 shows the current vs. potential curves for devices assembled with 1 up to 3 layers of $\mathrm{TiO}_{2}$ nanoparticle colloid solution with 5-6 micrometers each and by applying the methodology \#5 for sensitization.

The performance of devices assembled with 1 and 3 layers shows that the FF and Voc values are affected by the thickness of the films (Table 5), while the Isc values seem 
TABLE 5: Electrical and efficiency parameters of solar cells with different thicknesses of the $\mathrm{TiO}_{2}$ films, where Isc is the short circuit current density $\left(\mathrm{mA} \cdot \mathrm{cm}^{2}\right)$, Voc is the open circuit voltage $(\mathrm{V}), \mathrm{FF}$ is the fill factor (\%), and $\eta$ is the conversion efficiency (\%). The measurements were carried out under one sun $\left(100 \mathrm{~mW} \cdot \mathrm{cm}^{-2}\right)$ on masked cells (active area $0.19 \mathrm{~cm}^{2}$ ).

\begin{tabular}{lcccc}
\hline $\mathrm{TiO}_{2}$ thickness $(\mu \mathrm{m})$ & Isc & Voc & $\mathrm{FF}$ & $\eta$ \\
\hline 5 & 0.21 & 0.35 & 32 & 0.02 \\
12 & 0.28 & 0.41 & 64 & 0.07 \\
16 & 0.29 & 0.34 & 31 & 0.01 \\
\hline
\end{tabular}

not to be affected by the $\mathrm{TiO}_{2}$ thickness. Moreover, the device with a $5 \mu \mathrm{m}$ layer seems to indicate a higher resistance in parallel, generated by an existing recombination mechanism. In addition, the shape of the curves and the decrease in the FF and Voc values obtained for devices with 1 and 3 layers indicate that their thickness makes devices subject to higher resistance in series.

\section{Conclusions}

In this study, cationic carboxy heptamethine cyanines were synthesized with good yields. The photophysical characterization in methanol and DMF was performed in both ground and excited states using UV-Vis absorption and fluorescence emission spectroscopies and TD-DFT/PCM calculations. The obtained compounds showed absorption and emission in the Vis-NIR regions in the solution. The photophysical characterization in the solid state indicated that these compounds presented excellent adsorption on $\mathrm{TiO}_{2}$, which can be justified by the presence of the carboxylic groups. The decrease of $\mathrm{H}$-aggregate formation was observed by the addition of deoxycholic acid as a coadsorbent. The systematic study carried out to suppress aggregation of these dyes in the solid state allowed us to obtain an optimized methodology for sensitizing $\mathrm{TiO}_{2}$ with the lowest number of $\mathrm{H}$ aggregates. Cyclic voltammetry indicates that the LUMO values of the obtained cyanines are close to the edge of the $\mathrm{TiO}_{2}$ conduction band. However, the HOMO and LUMO of the cyanines respect the relative positions of the energy levels for allowing charge electrotransfer to occur. Finally, the application of the studied compounds as sensitizers for $\mathrm{TiO}_{2}$ in DSSCs showed their ability to contribute to the conversion of light into electrical energy. Additionally, when DSSCs were made by applying deoxycholic acid with compound 13 simultaneously, in the sensitization of $\mathrm{TiO}_{2}$ films, there was a considerable increase in the conversion efficiency, short circuit current density, open circuit voltage, and fill factor values.

\section{Data Availability}

The original data supporting this study are available in the supplementary files and also from the corresponding author upon request.

\section{Conflicts of Interest}

The authors declare that they have no conflicts of interest.

\section{Acknowledgments}

We are grateful to the Coordenação de Aperfeiçoamento de Pessoal de Nível Superior (CAPES)-Finance Code 001, CNPq (409855/2018-9 and 305954/2019-9), and FAPERGS (17/2551-0000968-1) for the financial support.

\section{Supplementary Materials}

spectroscopic characterization. Additional data for DSSC preparation. Theoretical calculations. Additional photophysical data. SEM images. (Supplementary Materials)

\section{References}

[1] J. L. Bricks, A. D. Kachkovskii, Y. L. Slominskii, A. O. Gerasov, and S. V. Popov, "Molecular design of near infrared polymethine dyes: a review," Dyes and Pigments, vol. 121, pp. 238-255, 2015.

[2] J. Yum, P. Walter, S. Huber et al., "Efficient far red sensitization of nanocrystalline $\mathrm{TiO}_{2}$ films by an unsymmetrical squaraine dye," Journal of the American Chemical Society, vol. 129, no. 34, pp. 10320-10321, 2007.

[3] L. Beverina, J. Fu, A. Leclercq et al., "Two-photon absorption at telecommunications wavelengths in a dipolar chromophore with a pyrrole auxiliary donor and thiazole auxiliary acceptor," Journal of the American Chemical Society, vol. 127, no. 20, pp. 7282-7283, 2005.

[4] P. A. Bouit, G. Wetzel, G. Berginc et al., "Near IR nonlinear absorbing chromophores with optical limiting properties at telecommunication wavelengths," Chemistry of Materials, vol. 19, no. 22, pp. 5325-5335, 2007.

[5] K. B. Male and J. H. T. Luong, "An improved enzymatic assay for glucose determination in blood serum using a $1,1^{\prime}$ -dimethylferricinium dye," Applied Biochemistry and Biotechnology, vol. 61, no. 3, pp. 267-276, 1996.

[6] C. Q. Zhu, H. Zheng, D. H. Li, S. H. Li, and J. G. Xu, "Nearinfrared hydrophobic probes as molecular light switch for cmc determination of triton X-100 solution," Chinese Journal of Chemistry, vol. 22, no. 11, pp. 1319-1324, 2004.

[7] L. Tarazi, N. Narayanan, and G. Patonay, "Investigation of the spectral properties of a squarylium near-infrared dye and its complexation with Fe(III) and $\mathrm{Co}(\mathrm{II})$ ions," Microchemical Journal, vol. 64, no. 3, pp. 247-256, 2000.

[8] M. I. Daneshvar, J. M. Peralta, G. A. Casay et al., "Detection of biomolecules in the near-infrared spectral region via a fiberoptic immunosensor," Journal of Immunological Methods, vol. 226, no. 1-2, pp. 119-128, 1999.

[9] J. Sowell, J. C. Mason, L. Strekowski, and G. Patonay, "Binding constant determination of drugs toward subdomain IIIA of human serum albumin by near-infrared dye-displacement capillary electrophoresis," Electrophoresis, vol. 22, no. 12, pp. 2512-2517, 2001.

[10] X. Yang, C. Shi, R. Tong et al., "Near IR heptamethine cyanine dye-mediated cancer imaging," Clinical Cancer Research, vol. 16 , no. 10 , pp. $2833-2844,2010$. 
[11] T. Geiger, I. Schoger, D. Rentsch et al., "Unsymmetrical heptamethine dyes for NIR dye-sensitized solar cells," International Journal of Photoenergy, vol. 2014, Article ID 258984, 10 pages, 2014.

[12] M. Matsui, Y. Hashimoto, K. Funabiki, J. Y. Jin, T. Yoshida, and H. Minoura, "Application of near-infrared absorbing heptamethine cyanine dyes as sensitizers for zinc oxide solar cell," Synthetic Metals, vol. 148, no. 2, pp. 147-153, 2005.

[13] T. Geiger, H. Benmansour, B. Fan, R. Hany, and F. Nüesch, "Low-band gap polymeric cyanine dyes absorbing in the NIR region," Macromolecular Rapid Communications, vol. 29, no. 8, pp. 651-658, 2008.

[14] W. Ghann, H. Kang, E. Emerson et al., "Photophysical properties of near-IR cyanine dyes and their application as photosensitizers in dye sensitized solar cells," Inorganica Chimica Acta, vol. 467, pp. 123-131, 2017.

[15] H. Zhang, G. Wicht, C. Gretener et al., "Semitransparent organic photovoltaics using a near-infrared absorbing cyanine dye," Solar Energy Materials \& Solar Cells, vol. 118, pp. 157164, 2013.

[16] T. Ono, T. Yamaguchi, and H. Arakawa, "Study on dyesensitized solar cell using novel infrared dye," Solar Energy Materials \& Solar Cells, vol. 93, no. 6-7, pp. 831-835, 2009.

[17] K. Funabiki, H. Mase, A. Hibino et al., "Synthesis of a novel heptamethine-cyanine dye for use in near-infrared active dye-sensitized solar cells with porous zinc oxide prepared at low temperature," Energy \& Environmental Science, vol. 4, no. 6, pp. 2186-2192, 2011.

[18] G. Chen, D. Yokoyama, H. Sasabe, Z. R. Hong, Y. Yang, and J. Kido, "Optical and electrical properties of a squaraine dye in photovoltaic cells," Applied Physics Letters, vol. 101, no. 8, article 083904, 2012.

[19] M. Ziółek, J. Karolczak, M. Zalas, Y. Hao, H. Tian, and A. Douhal, "Aggregation and electrolyte composition effects on the efficiency of dye-sensitized solar cells. A case of a near-infrared absorbing dye for tandem cells," The Journal of Physical Chemistry C, vol. 118, no. 1, pp. 194-205, 2013.

[20] K. Pydzińska and M. Ziółek, "Solar cells sensitized with nearinfrared absorbing dye: problems with sunlight conversion efficiency revealed in ultrafast laser spectroscopy studies," Dyes and Pigments, vol. 122, pp. 272-279, 2015.

[21] J. H. Yum, S. J. Moon, R. Humphry-Baker et al., "Effect of coadsorbent on the photovoltaic per-formance of squaraine sensitized nanocrystalline solar cells," Nanotechnology, vol. 19, no. 42, article 424005, 2008.

[22] C. H. Lee, H. J. Yun, M. R. Jung, J. G. Lee, S. H. Kim, and J. H. Kim, "Preparation and characterization of squaraine dyes containing mono-and bis-anchoring groups as the light absorber in dye sensitized solar cells," Electrochimica Acta, vol. 138, pp. 148-154, 2014.

[23] M. J. Frisch, G. W. Trucks, H. B. Schlegel et al., Gaussian 16, Revision A.03, Gaussian, Inc., Wallingford CT, 2016.

[24] Y. Zhao and D. G. Truhlar, "The M06 suite of density functionals for main group thermochemistry, thermochemical kinetics, noncovalent interactions, excited states, and transition elements: two new functionals and systematic testing of four M06-class functionals and 12 other functionals," Theoretical Chemistry Accounts, vol. 120, pp. 215-241, 2008.

[25] S. Grimme, J. Antony, S. Ehrlich, and H. Krieg, "A consistent and accurate $a b$ initio parametrization of density functional dispersion correction (DFT-D) for the 94 elements H-Pu,"
Journal of Chemical Physics, vol. 132, no. 15, pp. 154104154119, 2010.

[26] N. Minezawa, "Vertical excitation energies of linear cyanine dyes by spin-flip time-dependent density functional theory," Chemical Physics Letters, vol. 662, no. 16, pp. 115-119, 2015.

[27] D. Jacquemin, Y. Zhao, R. Valero, C. Adamo, I. Ciofini, and D. G. Truhlar, "Verdict: time-dependent density functional theory "not guilty" of large errors for cyanines," Journal of Chemical Theory and Computation, vol. 8, no. 4, pp. 12551259, 2012.

[28] B. Le Guennic and D. Jacquemin, "Taking up the cyanine challenge with quantum tools," Accounts of Chemical Research, vol. 48, no. 3, pp. 530-537, 2015.

[29] B. Mennucci, E. Cancès, and J. Tomasi, "Evaluation of solvent effects in isotropic and anisotropic dielectrics and in ionic solutions with a unified integral equation method: theoretical bases, computational implementation, and numerical applications," The Journal of Physical Chemistry B, vol. 101, no. 49, pp. 10506-10517, 1997.

[30] E. Cancès, B. Mennucci, and J. Tomasi, “A new integral equation formalism for the polarizable continuum model: theoretical background and applications to isotropic and anisotropic dielectrics," Journal of Chemical Physics, vol. 107, no. 8, pp. 3032-3041, 1997.

[31] E. Cancès and B. Mennucci, "New applications of integral equations methods for solvation continuum models: ionic solutions and liquid crystals," Journal of Mathematical Chemistry, vol. 23, no. 3/4, pp. 309-326, 1998.

[32] R. L. Martin, "Natural transition orbitals," The Journal of Chemical Physics, vol. 118, no. 11, pp. 4775-4777, 2003.

[33] R. C. Duarte, F. S. Santos, B. Bercini et al., "Synthesis of a 5-carboxy indole-based spiropyran fluorophore: thermal, electrochemical, photophysical and bovine serum albumin interaction investigations," Chemosensors, vol. 8, no. 2, pp. 2-17, 2020.

[34] C. F. H. Allen and C. V. Wilson, "The use of N15 as a tracer element in chemical reactions. The mechanism of the Fischer indole synthesis," Journal of the American Chemical Society, vol. 65, no. 4, pp. 611-612, 1943.

[35] G. O. Menéndez, M. E. Pichel, C. C. Spagnuolo, and E. A. Jares-Erijman, "NIR fluorescent biotinylated cyanine dye: optical properties and combination with quantum dots as a potential sensing device," Photochemical \& Photobiological Sciences, vol. 12, no. 2, pp. 236-240, 2013.

[36] A. Owens, N. Bruschi, J. G. Tawney, and M. Henary, "A microwave-assisted and environmentally benign approach to the synthesis of near-infrared fluorescent pentamethine cyanine dyes," Dyes and Pigments, vol. 113, pp. 27-37, 2015.

[37] H. Lee, C. Mason, and S. Achilefu, "Synthesis and spectral properties of near-infrared aminophenyl-, hydroxyphenyl-, and phenyl-substituted heptamethine cyanines," Journal of Organic Chemistry, vol. 73, no. 2, pp. 723-725, 2008.

[38] P. Qui and G. J. Meyer, "Proton-controlled electron injection from molecular excited states to the empty states in nanocrystalline $\mathrm{TiO}_{2}$," Langmuir, vol. 17, no. 21, pp. 6720-6728, 2001.

[39] J. R. De Lile, S. G. Kang, Y. -A. Son, and S. G. Lee, "Do HOMO-LUMO energy levels and band gaps provide sufficient understanding of dye-sensitizer activity trends for water purification?," ACS Omega, vol. 5, no. 25, pp. 15052-15062, 2020.

[40] C. G. Zhan, J. A. Nichols, and D. A. Dixon, "Ionization potential, electron affinity, electronegativity, hardness, and electron 
excitation energy: molecular properties from density functional theory orbital energies," The Journal of Physical Chemistry A, vol. 107, no. 20, pp. 4184-4195, 2003.

[41] F. De Angelis, S. Fantacci, and A. Selloni, "Alignment of the dye's molecular levels with the TiO2band edges in dyesensitized solar cells: a DFT-TDDFT study," Nanotechnology, vol. 19, no. 42, article 424002, 2008.

[42] C. I. Oprea, P. Panait, Z. M. Essam, R. M. Abd El-Aal, and M. A. Gîrțu, "Photoexcitation processes in oligomethine cyanine dyes for dye-sensitized solar cells-synthesis and computational study," Nanomaterials, vol. 10, no. 4, p. 662, 2020.

[43] M. Gratzel, "Photoelectrochemical cells," Nature, vol. 414, no. 6861, pp. 338-344, 2001.

[44] X. Jin, D. Li, L. Sun, C. L. Wang, and F. Q. Bai, “Theoretical design of porphyrin sensitizers with different acceptors for application in dye-sensitized solar cells," RSC Advances, vol. 8, no. 35, pp. 19804-19810, 2018.

[45] C. Y. Qin and A. E. Clark, "DFT characterization of the optical and redox properties of natural pigments relevant to dyesensitized solar cells," Chemical Physics Letters, vol. 438, no. $1-3$, pp. 26-30, 2007.

[46] C. M. Cardona, W. Li, A. E. Kaifer, D. Stockdale, and G. C. Bazan, "Electrochemical considerations for determining absolute frontier orbital energy levels of conjugated polymers for solar cell applications," Advanced Materials, vol. 23, no. 20, pp. 2367-2371, 2011.

[47] R. Guliania, A. Jainb, and A. Kapoora, "Exact analytical analysis of dye-sensitized solar cell: improved method and comparative study," The Open Renewable Energy Journal, vol. 5, no. 1, pp. 49-60, 2012. 